\title{
Targeting hypoxic tumor cell viability with carbohydrate-based carbonic anhydrase IX and XII inhibitors
}

Jason C. Morris, ${ }^{\dagger}$ Johanna Chiche, ${ }^{\ddagger}$ Caroline Grellier, ${ }^{\dagger}$ Marie Lopez, $^{\dagger}$ Laurent F. Bornaghi, $^{\dagger}$ Alfonso Maresca, ${ }^{\S}$ Claudiu T. Supuran, ${ }^{\S}$ Jacques Pouysségur ${ }^{\ddagger}$ and Sally-Ann Poulsen ${ }^{\dagger, *}$

${ }^{\dagger}$ Eskitis Institute for Cell and Molecular Therapies, Griffith University, Nathan, Queensland 4111, Australia, §Polo Scientifico, Laboratorio di Chimica Bioinorganica, Rm. 188, Università degli Studi di Firenze, Via della Lastruccia 3, 50019 Sesto Fiorentino, Florence, Italy, and ${ }^{\ddagger}$ Institute of Developmental Biology and Cancer, CNRS UMR654 3, University of Nice, Centre Antoine Lacassagne, 33 av. de Valombrose 06189 Nice, France.

*Corresponding author. S.-A.P. Telephone: +61 73735 7825; Fax: +61 73735 7656; e-mail: s.poulsen@griffith.edu.au.

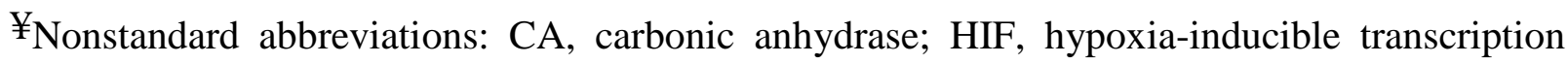
factor; $\mathrm{pH}_{0}$, extracellular $\mathrm{pH}$; $\mathrm{pH}_{\mathrm{i}}$, intracellular $\mathrm{pH}$; SAR, structure-activity relationships; $\mathrm{SPR}$, structure-property relationships; 1,3-DCR, 1,3-dipolar cycloaddition reaction; cLogP, calculated Log P; ELSD, evaporative light scattering detection; tet, tetracycline. 


\begin{abstract}
Carbonic anhydrase (CA) enzymes, specifically membrane-bound isozymes CA IX and CA XII, underpin a pH-regulating system that enables hypoxic tumor cell survival and proliferation. CA IX and XII are implicated as potential targets for the development of new hypoxic cancer therapies. To date only a few small molecules have been characterized in CArelevant cell and animal model systems. In this paper we describe the development of a new class of carbohydrate-based small molecule CA inhibitors, many of which inhibit CA IX and XII within a narrow range of low nanomolar $K_{\mathrm{i}}$ values (5.3-11.2 nM). We evaluate for the first time carbohydrate-based CA inhibitors in cell-based models that emulate the protective role of CA IX in an acidic tumor microenvironment. Our findings identified two inhibitors (compounds 5 and 17) that block CA IX-induced survival and have potential for development as in vivo cancer-cell selective inhibitors.
\end{abstract}




\section{Background}

Tumor cells alter their metabolism when in a low oxygen (hypoxic) microenvironment to survive, proliferate and metastasise. ${ }^{1}$ The hypoxia-inducible transcription factor (HIF-1) regulates gene expression of proteins that are responsible for alterations in hypoxic tumor cell metabolism - one core aspect of which is the shift from aerobic to fermentative glycolysis. ${ }^{2}$ Fermentative glycolysis leads to elevated lactic acid production, hence a drop in the intracellular $\mathrm{pH}\left(\mathrm{pH}_{\mathrm{i}}\right)$ of hypoxic tumor cells is expected unless $\mathrm{pH}$ homeostasis is established. ${ }^{3}$ Carbonic anhydrase (CA, EC 4.2.1.1) enzymes, specifically isozymes CA IX and CA XII, have been shown to underpin a robust $\mathrm{pH}$-regulating system by maintaining a $\mathrm{pH}_{\mathrm{i}}$ range compatible with cell viability and proliferation, while they contribute to the extracellular acidification of the tumor microenvironment. These enzymes confer a survival advantage to tumor cells growing in a hypoxic and acidic microenvironment. ${ }^{4}$ CAs catalyze the reversible hydration of carbon dioxide $\left(\mathrm{CO}_{2}\right)$ to generate a bicarbonate anion $\left(\mathrm{HCO}_{3}^{-}\right)$and a proton $\left(\mathrm{H}^{+}\right) .{ }^{5} \mathrm{CA}$ IX and XII differ from cytosolic CAs in that they are transmembrane proteins with an extracellular catalytic domain. ${ }^{5}$ A characterized role of CA IX and XII in cancer is the hydration of tumor cell generated $\mathrm{CO}_{2}$, the net effect is to trap $\mathrm{H}^{+}$extracellularly, lowering $\mathrm{pH}$ outside the cell $\left(\mathrm{pH}_{\mathrm{o}}\right)$ whilst maintaining normal $\mathrm{pH}_{\mathrm{i}}{ }^{3,}{ }^{6} \mathrm{CA}$ IX and XII expression is upregulated in a wide variety of human tumors under the control of HIF-1, CA IX is commonly absent in corresponding normal tissue (except the stomach and GI tract), while CA XII is expressed in a selection of normal tissues. ${ }^{7}$ The impact of modulating CA activity on tumor growth was recently affirmed in a set of in vivo studies in mice. ${ }^{4}$ These studies demonstrated that silencing of ca9 and ca12 genes using shRNA significantly reduced the rate of xenograft growth and this outcome was attributed to slowed proliferation in the absence of membrane-associated CAs. In humans, studies targeting CA IX-expressing cells using immunotherapy with the monoclonal antibody G250, have reached clinical trials for the treatment of patients with metastatic renal 
cell carcinoma. ${ }^{8}$ Based on the in vivo mouse results using genetic silencing and success with immunotherapy in human cancer patients, the modulation of CA IX and XII with small molecule inhibitors represents a mechanistically novel opportunity with potential for anticancer therapy intervention. From the perspective of targeted cancer therapeutics, this hypothesis has generated scientific interest that so far remains to be comprehensively explored. To date only a few small molecules have been characterized in CA-relevant cell and animal model systems. ${ }^{9}$ CA inhibitors that incorporate a hydrophilic moiety such as a cationic pyridinium ${ }^{10,11}$ and 'Cp*Ru(II)' salts ${ }^{12}$ or carbohydrate moieties ${ }^{13-17}$ have been developed to have limited membrane permeability and so may better target CA IX and XII over CA II.

In order to characterize the potential effect of inhibition of CA IX and XII in tumor hypoxia there is an implied need to develop small molecule, cell impermeable CA inhibitors for use in cell-based models of these extracellular, cancer-linked CAs in tumor hypoxia. Once characterized these molecules should have value as probes to further aid experimental advances in targeted cancer therapies associated with CA and tumor pH homeostasis. ${ }^{4,17}$ Our group's research has focussed on small molecule medicinal chemistry of CA inhibitors, and we recently reported a library of $S$-glycosides that were potent inhibitors of CA isozymes IX and XII in vitro. ${ }^{18}$ Encouraged by the nanomolar activity of these compounds we now elaborate this novel compound class and evaluate for the first time carbohydrate-based CA inhibitors in cell-based models that emulate the role of CA IX in an acidic tumor microenvironment.

\section{Results and Discussion}

Compound Design. Sugar-based molecules have proven valuable drug leads, often presenting desirable activity and safety profiles. ${ }^{19}$ Many of the sugar-based drugs in clinical use are 
antiviral, antibacterial or antifungal ${ }^{20}$ and benefit from improved solubility, tolerability, stability and/or targeting when compared to non-carbohydrate drugs. Work in our research group has demonstrated the versatility of the $\mathrm{Cu}(\mathrm{I})$ catalyzed 1,3-dipolar cycloaddition reaction (1,3-DCR or 'click chemistry') of organic azides and acetylenes to generate 1,2,3-triazole glycoconjugates. ${ }^{13}$ We have developed small molecule membrane impermeable carbohydratebased CA inhibitors from alkynyl sugars and $p$-azidobenzene sulfonamide, ${ }^{14,18}$ as well as the 'reverse polarity' inhibitors from azido sugars and p-ethynylbenzene sulfonamide. ${ }^{15}$ These compounds were designed to selectively target cancer relevant CA isozymes (with an extracellular active site) over other (intracellular) CA isozymes. ${ }^{13 b, 14-16}$ Compounds comprise a hydrophilic sugar moiety tethered to an aromatic sulfonamide CA pharmacophore through an intervening triazole ring to provide a selection of membrane impermeable small molecule CA inhibitors.

The replacement of the naturally occurring $O$-glycoside bond by a $S$-glycoside bond is an approach practiced in the synthesis of carbohydrate containing compounds for downstream biological applications. This isosteric replacement seeks to enhance the stability of the small molecule glycoside towards enzymatic hydrolysis of the glycosidic bond whilst retaining vital molecular recognition interactions with the biological target. ${ }^{21}$ We have reported the synthesis and CA enzyme inhibition of $S$-linked glucose and galactose moieties tethered to a triazole$\mathrm{ArSO}_{2} \mathrm{NH}_{2}$ motif, Figure $1 \mathrm{a}^{18}$ Our intention here is to build structure-activity relationships (SAR) and structure-property relationships (SPR) around this compound class that can value add to the interpretation of CA inhibitor behaviour in cell-based assays. The target compounds of the present study were thus designed to incorporate a synthetic-handle that would allow further elaboration of the structure to 1,4,5-trisubstituted-1,2,3-triazoles. Specifically we chose 
to incorporate an iodine atom at the 5 position of the triazole moiety of the target compounds, Figure 1b, this modification is key to further developing our molecular library.

a)

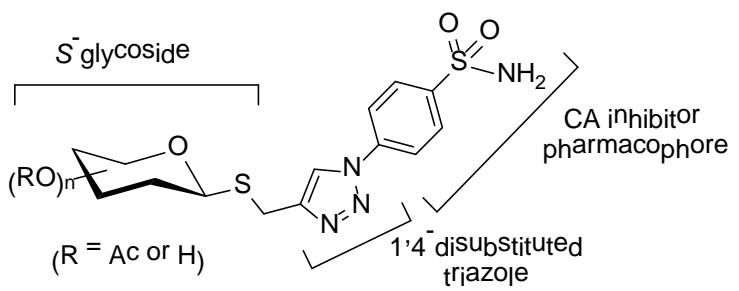

b)

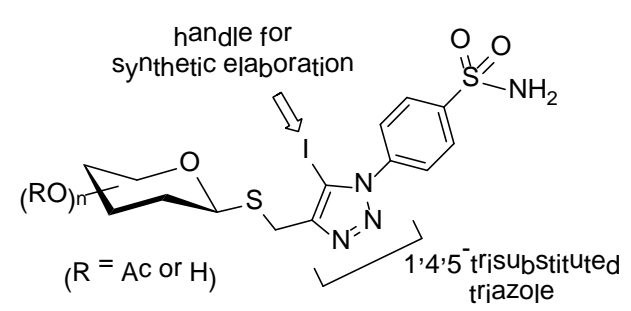

Figure 1. a) S-glycoside 1,4-disubstituted-1,2,3-triazole CA inhibitor motif. b) S-glycoside 5iodo-1,4-disubstituted-1,2,3-triazole CA inhibitor motif.

\section{Chemistry.}

${\text { Both } \text { Meldal }^{22} \text { and Sharpless }}^{23}$ discovered that catalytic $\mathrm{Cu}(\mathrm{I})$ leads to a dramatic rate enhancement (up to $10^{7}$-fold) of the 1,3-dipolar cycloaddition reaction (1,3-DCR) of organic azides $\left(\mathrm{R}-\mathrm{N}_{3}\right)$ with alkynes $\left(\mathrm{R}^{\prime}-\mathrm{C} \equiv \mathrm{CH}\right)$ with exclusive synthesis of the 1,4-disubstituted-1,2,3triazole product. The reaction is now referred to as the copper-catalyzed azide-alkyne cycloaddition (CuAAC) and has rapidly become the foremost click chemistry reaction. ${ }^{24,25} \mathrm{~A}$ recent variation to CuAAC involves the combination of a CuI/NBS catalytic system. ${ }^{26}$ This variation allows the in situ generation of $\mathrm{I}^{+}$and facilitates the formation of the 5-iodo-1,4disubstituted 1,2,3-triazole product. We have applied this methodology to sugar alkyne and $p$ azidobenzene sulfonamide substrates, Scheme 1. In our hands this system generates two reaction products in similar yields, these are the 5-iodo- (Figure 1b) and the 5- $\mathrm{H}$ - triazoles (Figure 1a). We reconcile the formation of the two products to have resulted from competing reaction pathways, one in which the triazole-Cu intermediate is captured by $\mathrm{I}^{+}$(giving the 5iodo- product) and the second where this intermediate is protonated (giving the 5-H- product). 
This click chemistry variant thus gave useful quantities of two products both of which were valuable to the subsequent SAR and SPR investigations of CA inhibition.

We synthesized a set of triazole-based glycoconjugate sulfonamides 5-10 from $p$-azidobenzene sulfonamide 1 and peracetylated $\beta$-S-propynyl glycoside derivatives 2-4 in the presence of CuI and NBS, Scheme 1. Oxidation of the 5-iodo- $(5,7,9)$ and 5-H- $(\mathbf{6}, \mathbf{8}, \mathbf{1 0})$ 1,2,3-triazole benzenesulfonamide glycoconjugates to the corresponding sulfonyl derivatives 11-16 was achieved with an excess of $m$-CPBA. Deacetylation of the sugar moieties of glycoconjugate compounds was conducted using the standard Zemplén conditions ${ }^{27}$ of $0.05 \mathrm{M}$ sodium methoxide in methanol, to afford compounds 17-26.

Scheme 1. Synthesis of target S-glycoside 5-iodo-1,4-disubstituted-1,2,3-triazole and glycoside 5-H-1,4-disubstituted-1,2,3-triazole CA inhibitor compounds.

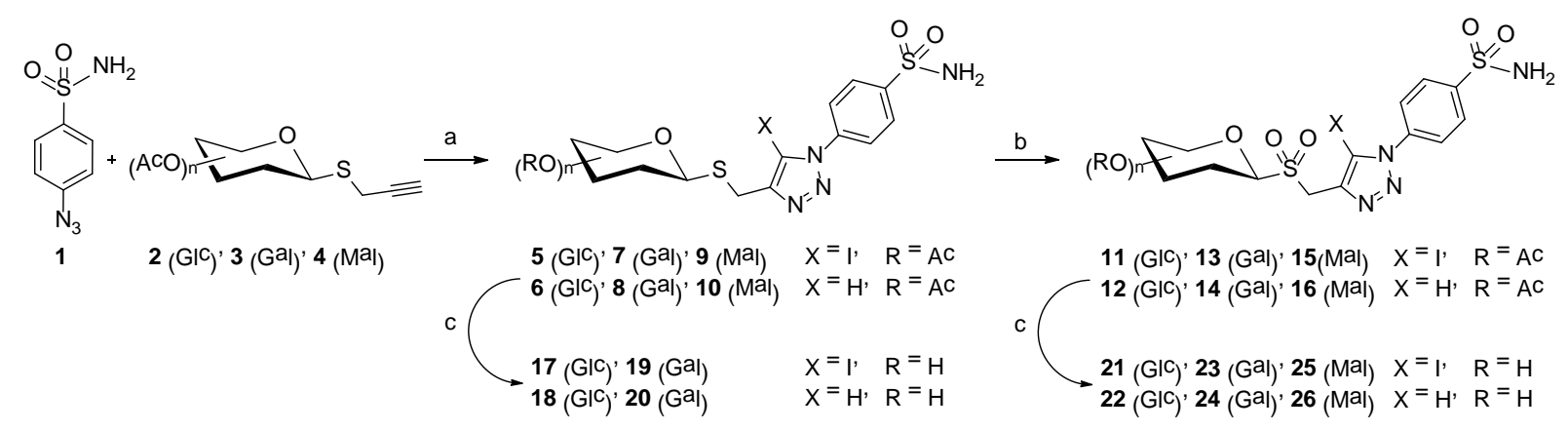

Reagents and conditions. a) peracetylated $\beta$-S-propynyl glycoside (2-4, 1.0 equiv.), azide (1, 1.2 equiv.), CuI (1.2 equiv.), DIPEA (1.2 equiv.), NBS (1.2 equiv.), THF, rt, 16 h. b) m-CPBA (7.0 equiv), anhydrous $\mathrm{CH}_{2} \mathrm{Cl}_{2}, 0{ }^{\circ} \mathrm{C}-\mathrm{rt}, 2$ h. c) $\mathrm{NaOMe}$ in $\mathrm{MeOH}$ (0.05 M, pH 12), anhydrous $\mathrm{MeOH}, 0^{\circ} \mathrm{C}-\mathrm{rt}, 30 \mathrm{~min}-16 \mathrm{~h}$. 
Chen et al. has recently demonstrated the application of the Sonogashira reaction to introduce an alkyne onto the 5-iodo-1,4-disubstituted triazole scaffold catalyzed by $\mathrm{PdCl}_{2}\left(\mathrm{PPh}_{3}\right)_{2}(10$ mol\%) and $\mathrm{K}_{2} \mathrm{CO}_{3}$ reporting both the ease and efficiency of the reaction $(71-99 \%) .{ }^{28}$ Here we explored this chemistry with our iodo substrates, compounds 5 and 7, and the alkyne, propargyl alcohol. This short chain alkyne was chosen as it provides a hydroxyl functional group that is capable of picking up additional H-bonding interactions with the target CA protein with minimal additional steric bulk. A variety of Sonogashira reaction conditions were explored, many proceeded with either no conversion of the starting material, or starting material decomposition. The coupling reaction between the 5-iodo triazoles and alkyne was however achieved when using $\mathrm{Pd}\left(\mathrm{PPh}_{3}\right)_{4}$, $\mathrm{CuI}$ and $\mathrm{Et}_{3} \mathrm{~N}$ to give 1,4,5-trisubstituted triazoles 27 and 28, Scheme 2. This synthetic strategy has provided an additional layer of diversity within this class of CA inhibitor.

Scheme 2. Synthesis of target $S$-glycoside-1,4,5-trisubstituted-1,2,3-triazole CA inhibitors, compounds 27 and 28.

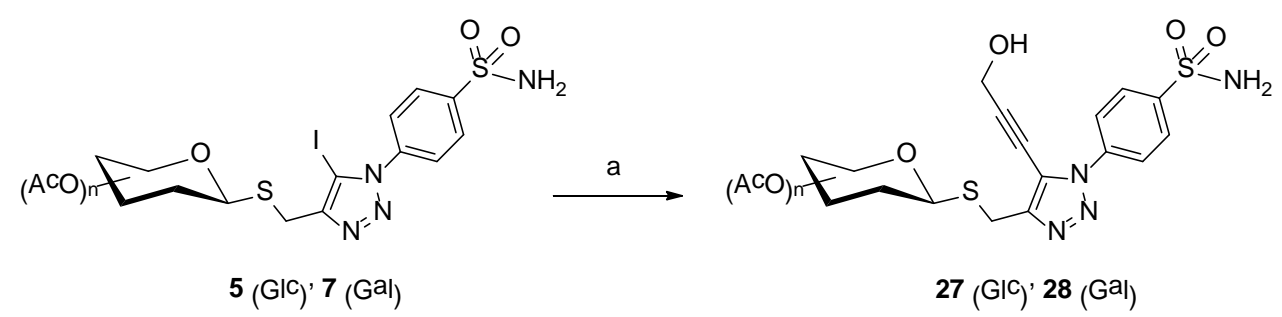

Reagents and conditions. CuI (1.0 equiv.), triethylamine (1.0 equiv.), propargyl alcohol (1.0 equiv.) in THF, nitrogen atmosphere, rt, 30 min; then $\mathrm{Pd}\left(\mathrm{PPh}_{3}\right)_{4}(1.0$ equiv. in THF) is added, $50{ }^{\circ} \mathrm{C}, 30 \mathrm{~min}$.

Carbonic Anhydrase Inhibition. The enzyme inhibition data for $\mathbf{5 - 2 8}$ as well as acetazolamide (AZA) were obtained for the physiologically dominant CA I and II, and tumorassociated CA IX and XII using a stopped flow assay that monitors the physiological reaction 
(CA catalyzed hydration of $\mathrm{CO}_{2}$ ), Table $1 .^{29} \mathbf{A Z A}$ is a clinically used CA inhibitor. Similarly to AZA the S-glycosides 5-26 were potent inhibitors of hCA II, IX and XII, most within a range of narrowly distributed $K_{\mathrm{i}}$ values (5.3-11.2 nM) with $K_{\mathrm{i}}$ selectivity ratios close to unity, with only a few exceptions. The tight distribution of $K_{\mathrm{i}}$ values on inhibitor activity for CA enzymes is consistent with our previously reported observations with this enzyme class. ${ }^{16 a}$, 30 This flat SAR showing minimal effect of compound structural variation on inhibition provides a valuable set of compounds as the presence of underlying consistent and high potency enzyme inhibition characteristics allows the relationship between physicochemical properties of the inhibitor and the performance in cell-based assays to be readily garnished. At hCA I inhibition by 5-26 was typically weaker (10-20 -fold) than for all other isozymes with $K_{\mathrm{i}} \mathrm{s}$ in the high $\mathrm{nM}$ to low $\mu \mathrm{M}$ range and is also consistent with earlier studies with this compound class. ${ }^{16 a}$ The two trisubstituted compounds, $\mathbf{2 7}$ and $\mathbf{2 8}$ - both with a short hydroxyl bearing group at the 5 position on the triazole, demonstrated some noteworthy SAR regarding isozyme selectivity for the cancer-associated CAs. Compound $\mathbf{2 8}$ has much lower inhibition for both cytosolic CAs compared to all other compounds of this study, as a consequence it has much better selectivity for the cancer-associated CAs, particularly CA XII, where the $K_{\mathrm{i}}$ is $9.0 \mathrm{nM}$ and selectivity over CA II is 24-fold.

Table 1. Inhibition and isozyme selectivity ratio data of CA isozymes I, II, IX and XII with 528 and the established drug and CA inhibitor, acetazolamide (AZA).

$$
K_{\mathrm{i}} \mathrm{s}^{a} K_{\mathrm{i}} \text { Selectivity Ratios }{ }^{b}
$$

\section{Compound}

\section{CA II/ CA II/}

\section{CA I CA II CA IX CA XII}

CA IX CA XII

AZA 


\begin{tabular}{|c|c|c|c|c|c|c|}
\hline 5 & 112 & 5.3 & 6.2 & 10.0 & 0.85 & 0.53 \\
\hline 6 & 91 & 5.3 & 8.6 & 9.6 & 0.62 & 0.55 \\
\hline 7 & 115 & 11.2 & 95 & 8.9 & 0.12 & 1.3 \\
\hline 8 & 117 & 9.9 & 8.6 & 9.2 & 1.15 & 1.08 \\
\hline 9 & nd & nd & nd & nd & - & - \\
\hline 10 & nd & nd & nd & nd & - & - \\
\hline 11 & 103 & 10.6 & 71 & 8.6 & 0.15 & 1.2 \\
\hline 12 & 97 & 6.9 & 9.3 & 9.1 & 0.74 & 0.76 \\
\hline 13 & 4070 & 38.5 & 97 & 9.1 & 0.40 & 4.2 \\
\hline 14 & 79 & 5.3 & 7.5 & 10.9 & 0.71 & 0.48 \\
\hline 15 & 101 & 49.8 & 99.6 & 59.2 & 0.50 & 1.2 \\
\hline 16 & 184 & 44.5 & 61.9 & 53.1 & 0.72 & 0.84 \\
\hline 17 & 119 & 5.5 & 6.5 & 10.7 & 0.85 & 0.51 \\
\hline 18 & 114 & 5.6 & 257 & 9.5 & 0.02 & 0.59 \\
\hline 19 & 119 & 10.7 & 7.3 & 7.8 & 1.47 & 1.4 \\
\hline 20 & 60 & 6.2 & 6.1 & 10.3 & 1.02 & 0.60 \\
\hline 21 & 3920 & 49.2 & 61 & 5.3 & 0.81 & 9.3 \\
\hline 22 & 101 & 7.6 & 9.5 & 10.3 & 0.80 & 0.74 \\
\hline 23 & 3730 & 37.9 & 89 & 9.4 & 0.43 & 4.0 \\
\hline 24 & 60 & 7.8 & 8.1 & 9.4 & 0.96 & 0.83 \\
\hline 27 & 142 & 59.5 & 68.0 & 11.7 & 0.88 & 5.1 \\
\hline 26 & 632 & 48.2 & 71.2 & 56.0 & 0.68 & 0.86 \\
\hline 27 & 105 & 11.9 & 72 & 7.9 & 0.17 & 1.5 \\
\hline 28 & 6860 & 219 & 91 & 9.0 & 2.4 & 24.3 \\
\hline
\end{tabular}


${ }^{a}$ Errors in the range of $\pm 5 \%$ of the reported value, from three determinations. ${ }^{b}$ The $K_{\mathrm{i}}$ ratios are indicative of isozyme selectivity for cancer-associated CAs in vitro and are calculated as $K_{\mathrm{i}} \mathrm{CA} I \mathrm{I} / K_{\mathrm{i}}$ CA IX or XII

Cell-based screening of CA inhibitors. To evaluate the impact of the CA inhibitors in cells we used our previously described in vitro systems of fibroblasts lacking endogenous expression of CA IX (CCL39-nhe1- -pev, also named PS120-pev) and fibroblasts that overexpress the human form of CA IX (CCL39-nhe1-pca9, also named PS120-pca9). ${ }^{4}$ Exposure of both these cell types to nominally $\mathrm{HCO}_{3}{ }^{-}$-free media at two external $\mathrm{pH}_{\mathrm{o}}(7.5$ or 6.4) can discriminate their viability. Exposure at $\mathrm{pH}_{\mathrm{o}} 7.5$ does not affect cell viability, while exposure at $\mathrm{pH}_{0} 6.4$ sharply discriminates PS120 cells that are expressing or not CA IX. Indeed at this acidic external $\mathrm{pH}_{0}$ 6.4 PS120-pev cells die while the PS120-pca9 remain viable. ${ }^{4}$ This differential survival under physiological $\mathrm{pH}$ versus acidic conditions is directly linked to the capacity of CA IX expressing cells to maintain a more alkaline $\mathrm{pH}_{\mathrm{i}}$ ensuring cell survival. PS120-pev cells (lacking CA IX expression) when grown in the neutral media system provide a control cell-based assay that allows us to evaluate the S-glycoside CA inhibitors for generic cytotoxicity. PS120-pca9 cells (overexpressing CA IX) when grown in the acidic media system provide a cell-based assay that allows us to evaluate the impact of $S$-glycoside CA inhibition on CA IX mediated cell viability. Together these two cell lines provide a cell-based model to study the likely effect of inhibition of CA IX in tumors with small molecules. ${ }^{4}$

We focussed arbitrarily on the $S$-glucoside panel of compounds $(5, \mathbf{6}, \mathbf{1 1}, \mathbf{1 2}, \mathbf{1 7}, \mathbf{1 8}, \mathbf{2 1}, \mathbf{2 2})$ and the classical CA inhibitor drug AZA to study in the cell-based systems. The subset of eight S-glucoside compounds allow us to evaluate the full cross section of SAR and SPR. Compounds incorporate a spread of 5-iodo- $(5, \mathbf{1 1}, \mathbf{1 7}, \mathbf{2 1})$ versus $5-\mathrm{H}-(\mathbf{6}, \mathbf{1 2}, \mathbf{1 8}, \mathbf{2 2})$ triazoles, acetylated $(5, \mathbf{6}, \mathbf{1 1}, \mathbf{1 2})$ versus deacetylated $(\mathbf{1 7}, \mathbf{1 8}, \mathbf{2 1}, \mathbf{2 2})$ sugars and sulfur in two oxidation states: $-\mathrm{S}-(\mathbf{5}, \mathbf{6}, \mathbf{1 7}, \mathbf{1 8})$ and $-\mathrm{SO}_{2-}(\mathbf{1 1}, \mathbf{1 2}, \mathbf{2 1}, \mathbf{2 2})$. These compounds also encompass a range 
of calculated Log P (cLog P) values, Table 2. cLog P represents intrinsic lipophilicity and compounds with $\log \mathrm{P}<0$ (such as $17,18,12,21$, and 22) typically have poor passive membrane permeability. All S-glucosides were potent CA II inhibitors ( $K_{\mathrm{i}}$ range 5.3-10.6 nM) with only compound 21 slightly weaker, yet still reasonably potent $\left(K_{\mathrm{i}}=49.2 \mathrm{nM}\right)$. Similarly all $S$-glucosides were potent CA XII inhibitors ( $K_{\mathrm{i}}$ range 5.3-10.7 nM) inhibitors, while 5, 6, 17, 12 and 22 were potent CA IX inhibitors $\left(K_{\mathrm{i}}<10 \mathrm{nM}\right)$, with 18, 11 and 21 less potent but still good CA IX inhibitors.

The effect of the S-glucoside CA inhibitors on cell viability on the two fibroblastic cell lines expressing or not CA IX is summarized in Table 2. Cells remained viable in the presence of the 5-H-triazole compounds $(\mathbf{6}, \mathbf{1 8}, \mathbf{1 2}, \mathbf{2 2})$ at the highest concentration tested $(300 \mu \mathrm{M})$ when grown at $\mathrm{pH}_{\mathrm{o}}$ 7.5. These compounds also had no impact on the CA IX-mediated cell viability at $\mathrm{pH}_{\mathrm{o}}$ 6.4, except for compound 6 which reduced cell viability only at $300 \mu \mathrm{M}$. Of the 5-iodo substituted compounds $(5, \mathbf{1 1}, \mathbf{1 7}, \mathbf{2 1})$, cells grown at $\mathrm{pH}_{\mathrm{o}} 7.5$ remained viable in the presence of $\mathbf{1 7}$ at the highest concentration tested $(300 \mu \mathrm{M})$, in the presence of $\mathbf{2 1}$ at $100 \mu \mathrm{M}$, in the presence of $\mathbf{5}$ at $60 \mu \mathrm{M}$, and in the presence of compound $\mathbf{1 1}$ at $30 \mu \mathrm{M}$. Compound 21 reduced cell viability of CA IX-expressing cells in acidic conditions $\left(\mathrm{pH}_{\mathrm{o}} 6.4\right)$ only at $300 \mu \mathrm{M}$, while compound 17 reduced viability of these cells at $100 \mu \mathrm{M}$. At a lower concentration $(60 \mu \mathrm{M})$ only compound 5 was not able to sustain viability at the acidic environment $\left(\mathrm{pH}_{\mathrm{o}} 6.4\right)$. AZA reduced viability only at $300 \mu \mathrm{M}$, however there was also no cell type or $\mathrm{pH}_{\mathrm{o}}$ selectivity.

Table 2. Cell viability assays on CA IX-expressing cell model PS120-pca9 versus CA IX lacking cell model PS120-pev treated with S-glucoside compounds and AZA. The calculated Log P value is also included. 


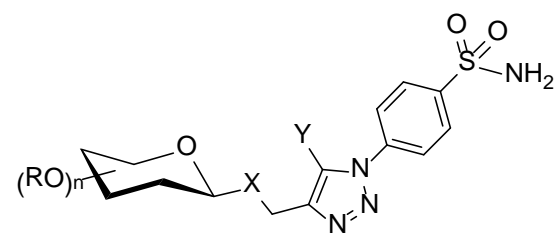

\begin{tabular}{|c|c|c|c|c|c|c|c|}
\hline Compound & $X$ & $\mathrm{Y}$ & $\mathrm{R}$ & $\operatorname{cLog} \mathrm{P}^{a}$ & $\begin{array}{c}K_{\mathrm{i}} \\
\text { at CA IX }\end{array}$ & $\begin{array}{c}\text { Cell viability } \\
\left(\mathrm{pH}_{\mathrm{o}} 7.5\right) \\
300 / 100 / 60 / 30 \\
\mu \mathrm{M}^{b, d}\end{array}$ & $\begin{array}{c}\text { Cell viability } \\
\left(\mathrm{pH}_{\mathrm{o}} 6.4\right) \\
300 / 100 / 60 / 30 \\
\mu \mathrm{M}^{c, d}\end{array}$ \\
\hline AZA & - & - & - & -0.98 & 25 & $-/+/+/+$ & $-/+/+/+$ \\
\hline 5 & S & I & Ac & +1.98 & 6.2 & $-/-/+/+$ & $-/-/-/+$ \\
\hline 6 & S & $\mathrm{H}$ & Ac & +1.10 & 8.6 & $+/+/+/+$ & $-/+/+/+$ \\
\hline 17 & S & I & $\mathrm{H}$ & -0.16 & 6.5 & $+/+/+/+$ & $-/-/+/+$ \\
\hline 18 & S & $\mathrm{H}$ & $\mathrm{H}$ & -1.04 & 257 & $+/+/+/+$ & $+/+/+/+$ \\
\hline 11 & $\mathrm{SO}_{2}$ & I & Ac & +0.54 & 71 & $-/-/-/+$ & $-/-/-/+$ \\
\hline 12 & $\mathrm{SO}_{2}$ & $\mathrm{H}$ & Ac & -0.34 & 9.3 & $+/+/+/+$ & $+/+/+/+$ \\
\hline 21 & $\mathrm{SO}_{2}$ & I & $\mathrm{H}$ & -1.60 & 61 & $-/+/+/+$ & $-/+/+/+$ \\
\hline 22 & $\mathrm{SO}_{2}$ & $\mathrm{H}$ & $\mathrm{H}$ & -2.48 & 9.5 & $+/+/+/+$ & $+/+/+/+$ \\
\hline
\end{tabular}

${ }^{a}$ CLog P data calculated using CS ChemDraw Ultra. ${ }^{b}$ Viability in PS120-pev and PS120-pca9 cells exposed to a $\mathrm{pH}_{0} 7.5 .{ }^{c}$ Viability in PS120-pca9 cells exposed to a $\mathrm{pH}_{\mathrm{o}} 6.4 .^{{ }^{d}}+$ indicates cells are viable; - indicates cells are not viable.

Among the eight $S$-glycoside inhibitors tested we identified two inhibitors (compounds $\mathbf{5}$ and 17) that demonstrated selective toxicity for $\mathrm{PS} 120-\mathrm{pca9}$ cells growing in a $\mathrm{pH}_{\mathrm{o}} 6.4$ in vitro. 
The concentration of compound $\mathbf{1 7}$ needed to block CA IX-induced survival in the acidic media was however high $(100 \mu \mathrm{M})$ and $\mathbf{1 7}$ was less suited to follow-up in vitro and in vivo studies than compound $\mathbf{5}$. Compound 5 blocked the CA IX-mediated survival in the acidic environment at $60 \mu \mathrm{M}$ without general toxicity at $\mathrm{pH}_{\mathrm{o}} 7.5$ in both cell lines (Table 2, Figure 2A). Compound 5 (60 $\mu \mathrm{M}$ for $30 \mathrm{~min}$ ) reduced membrane-associated CA activity similarly to the level obtained in cells lacking CA IX (Figure 2B). Notably, $60 \mu \mathrm{M}$ of AZA was not as effective as compound 5 at either abolishing CA IX-mediated cell survival in extracellular acidic conditions (Figure 2A) or in reducing CA IX activity (Figure 2B). In addition compound 5 (60 $\mu \mathrm{M}$ for $60 \mathrm{~min})$ reduced the $\mathrm{pH}_{\mathrm{i}}$ of CA IX expressing PS120-pca9 cells exposed to a $\mathrm{pH}_{\mathrm{o}}$ of 6.4 by 0.2 units. Under the same conditions, $60 \mu \mathrm{M}$ of AZA had no impact (Figure 2C).

A

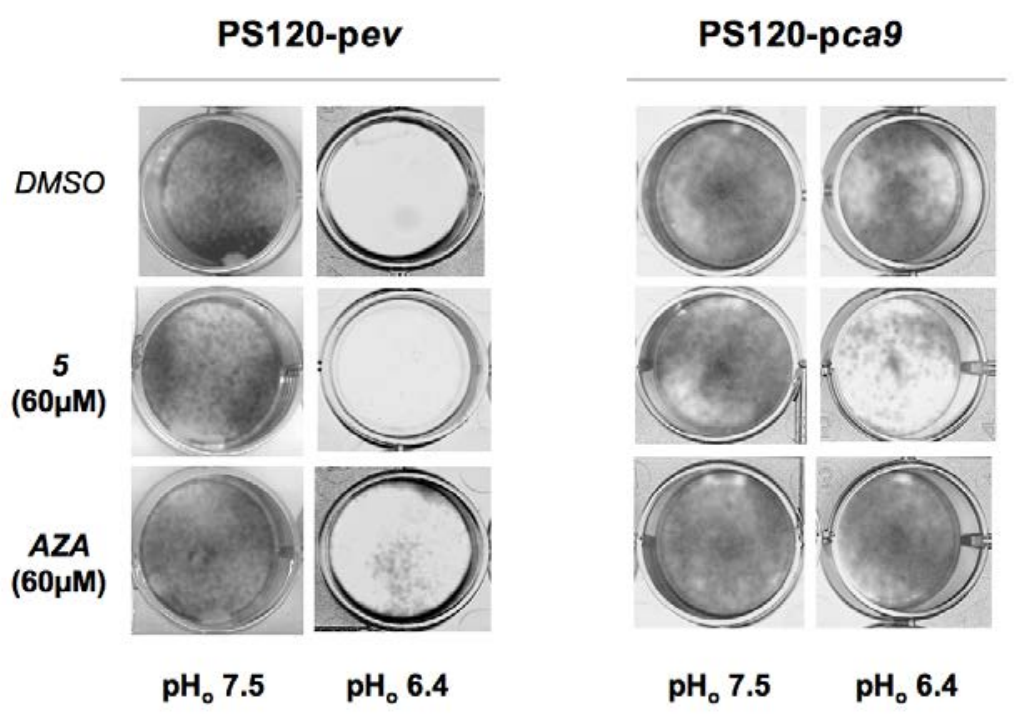


B

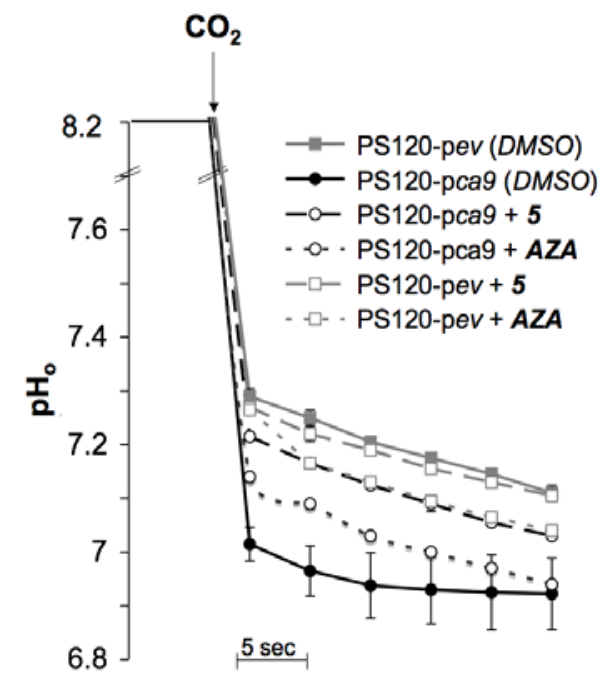

C

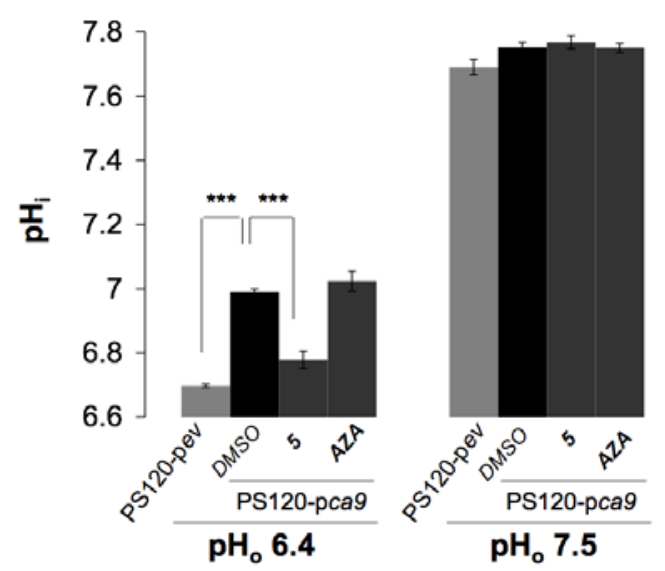

Figure 2: A. Cell viability assays for PS120-pev and PS120-pca9 cells in normoxia $\left(21 \% \mathrm{O}_{2}\right)$ as a function of the $\mathrm{pH}_{0}$. Once attached cells were incubated in a $\mathrm{HCO}_{3}{ }^{-}$-free media adjusted to $\mathrm{pH}_{0} 6.4$ or 7.5 for $24 \mathrm{~h}$ in a $\mathrm{CO}_{2}$-free atmosphere in the absence (DMSO control) or presence of $60 \mu \mathrm{M}$ of CA inhibitors AZA or compound 5. Fresh media containing $\mathrm{HCO}_{3}{ }^{-}(40 \mathrm{mM})$ at $\mathrm{pH}_{\mathrm{o}}$ 7.5 was then added and the assay maintained for 4 days in a $5 \% \mathrm{CO}_{2}$ incubator before staining to visualize the cell density.

B. Rate of extracellular acidification in response to a $\mathrm{CO}_{2}$-load on normoxic $\left(21 \% \mathrm{O}_{2}\right)$ PS120pev and PS120-pca9 cells. The rate of acidification reflects the CA activity at the cell surface evaluated in the absence (DMSO) or in the presence of $60 \mu \mathrm{M}$ of CA inhibitors (AZA or compound 5) 30 min prior $\mathrm{CO}_{2}$-loading. 
C. Compound $5(60 \mu \mathrm{M})$ but not AZA $(60 \mu \mathrm{M})$, reduces the resting $\mathrm{pH}_{\mathrm{i}}$ of CA IX-expressing PS120-pca9 cells in an acidic $\mathrm{HCO}_{3}{ }^{-}$-free media adjusted to $\mathrm{pH}_{\mathrm{o}}$ 6.4, but not $\mathrm{pH}_{\mathrm{o}}$ 7.5.

Next we investigated compound $\mathbf{5}$ in our human colon carcinoma cell model LS174Tr cells where we have previously demonstrated the in vitro and in vivo effects of knocking-down ca9 and ca12 genes via shRNA. ${ }^{4}$ Control LS-shca9/ctl -Tet cells induced both CA IX and CA XII in hypoxia (Figure 2A). CA IX expression was reduced with a specific shRNA targeting ca9 in control LS-shca9/ctl +Tet cells and in ca12-silenced LS-shca9/ca12- +Tet cells upon tetracycline (Tet) treatment. Following a 48-h treatment with $5(60 \mu \mathrm{M})$ we observed reduced levels of mRNA (data not shown) and protein for CA IX in the control (ca9-nonsilenced) cell line LS-shca9/ctl -Tet in normoxia $\left(\mathrm{N}, 21 \% \mathrm{O}_{2}\right)$ and hypoxia $\left(\mathrm{H}, 1 \% \mathrm{O}_{2}\right)$ (Figure 3A). We also observed the concomitant upregulation of CA XII expression in these cells at the mRNA and protein level (Figure 3A). The effect of compound 5 on CA IX and CA XII expression mirrors exactly that obtained by us earlier with tet-inducible shRNA targeting ca9 (LS-shca9/ctl +Tet) (Figure 3A). The lowest level of CA IX and CA XII ever observed in hypoxia was obtained in ca9 and ca12 double silenced cells (LS-shca9/ca12 +Tet) incubated with $60 \mu \mathrm{M}$ of compound 5. Under the same conditions, $60 \mu \mathrm{M}$ of AZA had no impact either on mRNA or protein levels of CA IX and CA XII (data not shown). Treatment of control colon LS-shca9/ctl -Tet cells with $5(60 \mu \mathrm{M})$ in hypoxia $\left(1 \% \mathrm{O}_{2}\right)$ showed a $60 \%$ decrease in cell proliferation after 3 days and an additional 16\% reduction on double-silenced LS-shca9/ca12- +Tet cells, consistent with the levels of CA IX and CA XII observed in these conditions (Figure 3B). 
A

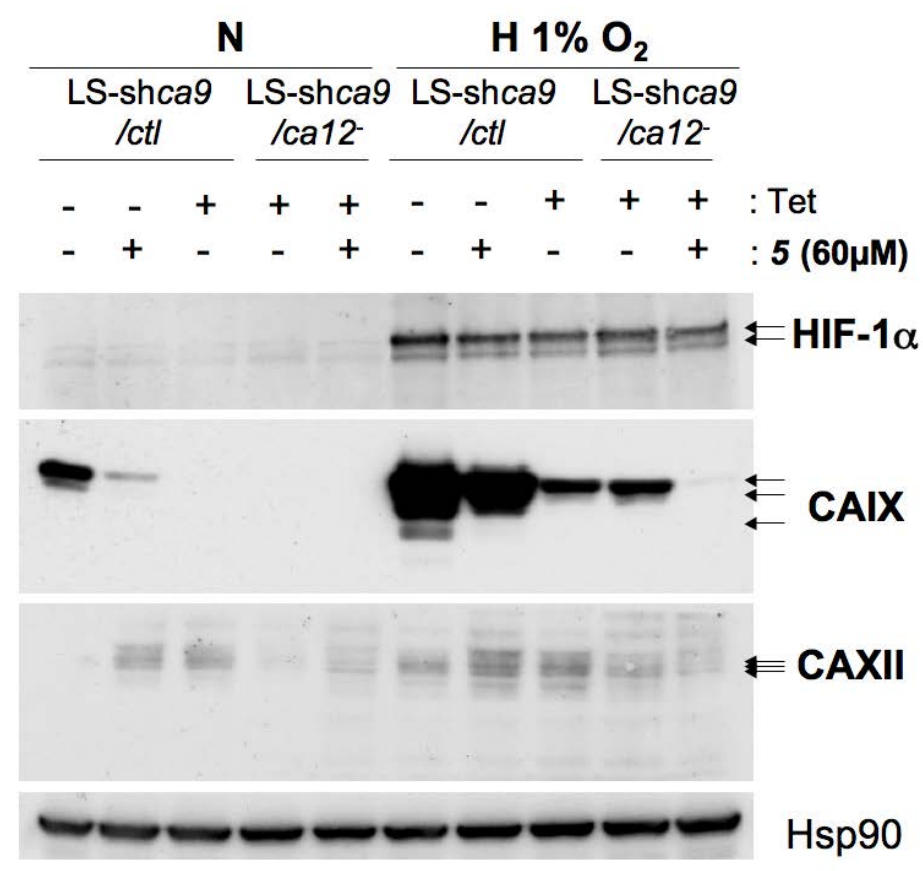

B

\section{$\mathrm{H} 1 \% \mathrm{O}_{2}$}
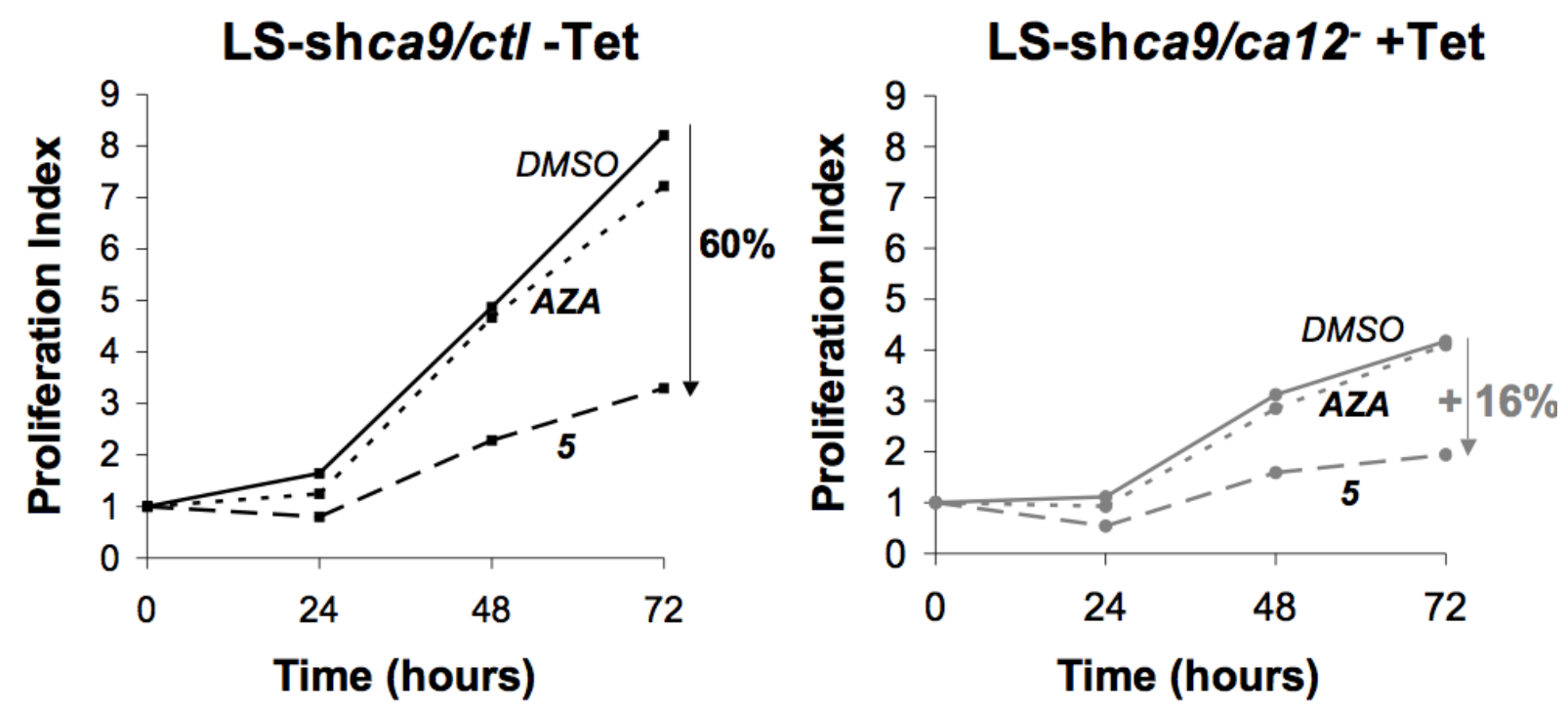

Figure 3: A. Impact of compound $5(60 \mu \mathrm{M})$ treatment on CA IX and CA XII expression in colon carcinoma cells: control cells (LS-shca9/ctl -Tet) or Tet-inducible ca9-silenced cells (LS-shca9/ctl +Tet) or double ca9- and ca12-silenced cells (LS-shca9/ca12- +Tet). Stable LSshca9/ctl and LS-shca9/ca12 cells were incubated with (+Tet) or without (-Tet) tetracyline for 4 days before incubation in either normoxia $\left(\mathrm{N}, 21 \% \mathrm{O}_{2}\right)$ or hypoxia $\left(\mathrm{H}, 1 \% \mathrm{O}_{2}\right)$ for $48 \mathrm{~h}$ in the 
absence (-) or in the presence (+) of $60 \mu \mathrm{M}$ of compound 5. Total cell extracts were analyzed by immunoblotting with antibodies against HIF-1 $\alpha$, CA IX, CA XII and Hsp90. The latter was used as a loading control.

B. Proliferation index of control LS-shca9/ctl -Tet cells or double silenced LS-shca9/ca12 +Tet cells exposed to hypoxia $\left(\mathrm{H}, 1 \% \mathrm{O}_{2}\right)$ for $48 \mathrm{~h}$ in the absence (DMSO) or in the presence of $60 \mu \mathrm{M}$ of CA inhibitors (AZA or compound 5). Total cell number was counted every $24 \mathrm{~h}$ during 3 days.

Our strategy to target the extracellular catalytic domain of cancer-associated CAs is to deliberately manipulate the physicochemical properties of the inhibitor to limit membrane permeability. Compound 5 has a clog $\mathrm{P}$ value $>0(+1.98)$ and thus is predicted to have some cell membrane permeability, while the cLog $\mathrm{P}$ for $\mathbf{1 7}$ is $<0(-0.16)$ and thus is predicted to be membrane impermeable. Despite their physicochemical difference these compounds were both identified as candidates that target CA IX in the cell models investigated. One explanation for the findings for compound 5 is that its high potency at CA IX $(\mathrm{Ki}=6.2 \mathrm{nM})$ demonstrates that it is a strong binder to CA IX, and even though it is likely to be membrane permeable CA IX may act as an extracellular trap or 'sink' for compound $\mathbf{5}$ as a consequence of the high binding affinity. In the absence of CA IX over expression compound $\mathbf{5}$ is likely to enter cells through passive diffusion, however when CA IX is over expressed at the cell surface compound $\mathbf{5}$ may still bind and have the desired effect.

\section{Conclusions}

Both genetic silencing and immunotherapy targeting the modulation of CA IX and/or XII activity has been shown effective in vivo for therapeutically targeting hypoxic tumours. Small molecule CA IX and XII inhibitors thus represent a mechanistically novel opportunity with 
potential for anticancer therapy intervention. From the perspective of targeted cancer therapeutics, this hypothesis so far remains to be comprehensively explored, and drug-like small molecule tools are needed to maximise the potential benefit of chemotherapies involving CA-mediated hypoxic tumor cell survival. We have designed and synthesized a new class of carbohydrate-based small molecule that very effectively inhibits both CA IX and XII enzymes. These inhibitors were studied in two fibroblast cell lines - one lacking endogenous expression of CA IX and one overexpressing CA IX. These in vitro systems allowed the discrimination of the protective role of CA IX in an acidic tumor microenvironment versus general cytotoxicity. Our findings identified two inhibitors (compounds 5 and 17) that selectively blocked CA IXinduced survival. Extended studies with compound $\mathbf{5}$ showed that it reduced membraneassociated CA activity to a similar level as that obtained in cells lacking CA IX. Compound 5 was also investigated in our human colon carcinoma cell model (LS174Tr cells) where we have previously demonstrated the beneficial in vitro and in vivo effects of knocking-down either ca9 or ca12 or both ca9 and ca12 genes with shRNA. Compound 5 reduced levels of mRNA and protein for CA IX in control (ca9-nonsilenced) colon carcinoma cells in normoxia and hypoxia, while CA XII expression was upregulated. Notably, the effect of compound 5 mirrors exactly that obtained by us earlier with shRNA targeting ca9 gene expression. The lowest level of CA IX and CA XII ever observed in hypoxia was obtained in ca9 and ca12 double-silenced colon carcinoma cells incubated with compound 5. Consistent with the levels of CA IX and CA XII expression observed, colon carcinoma cells in hypoxia treated with 5 showed a $60 \%$ decrease in cell proliferation after 3 days and an additional 16\% decrease in cell proliferation in ca9/ca12 double-silenced cells. Notably AZA, the clinically used CA inhibitor, was not as effective as compound $\mathbf{5}$ at either abolishing CA IX-mediated cell survival, reducing CA IX activity or reducing colon carcinoma cell proliferation. In summary, among the inhibitors tested herein two compounds were identified in this study that were able to 
effectively discriminate cell viability in CA IX/XII cell-based models. We have shown that compound 5 is a candidate small molecule mimetic of the shRNA targeting ca9 that we have used in our previous studies. We conclude that small molecule CA inhibitors have potential for development as effective in vivo cancer-cell selective inhibitors.

\section{Experimental Section}

\section{Chemistry - Materials and Methods}

All starting materials and reagents, including per-O-acetylated sugars, were purchased from commercial suppliers. All reactions were monitored by TLC. TLC plates were visualized with UV light, sulfuric acid stain $\left(5 \% \mathrm{H}_{2} \mathrm{SO}_{4}\right.$ in ethanol) and/or orcinol stain (1 $\mathrm{g}$ of orcinol monohydrate in a mixture of EtOH: $\mathrm{H}_{2} \mathrm{O}: \mathrm{H}_{2} \mathrm{SO}_{4}$ 72.5:22.5:5). Silica gel flash chromatography was performed using silica gel $60 \AA$ (230-400 mesh). ${ }^{1} \mathrm{H}$ NMR spectra were acquired at 500 $\mathrm{MHz}$ and ${ }^{13} \mathrm{C}$ NMR spectra at $125 \mathrm{MHz}$. Chemical shifts for ${ }^{1} \mathrm{H}$ and ${ }^{13} \mathrm{C}$ NMR spectra obtained in DMSO- $d_{6}$ are reported in ppm relative to residual solvent proton $(\delta=2.50 \mathrm{ppm})$ and carbon ( $\delta=39.5 \mathrm{ppm}$ ) signals, respectively. Chemical shifts for ${ }^{1} \mathrm{H}$ NMR spectra obtained in $\mathrm{CDCl}_{3}$ are reported in ppm relative to residual solvent proton $(\delta=7.26 \mathrm{ppm})$. Multiplicity is indicated as follows: s (singlet); d (doublet); t (triplet); m (multiplet); dd (doublet of doublet); ddd (doublet of doublet of doublet); br (broad). Coupling constants are reported in Hertz (Hz). Melting points are uncorrected. Mass spectra (low and high resolution) were recorded using electrospray as the ionization technique in positive ion negative ion modes as stated. All MS analysis samples were prepared as solutions in methanol. Optical rotations were measured at $25{ }^{\circ} \mathrm{C}$ and reported as an average of ten measurements. All compounds were analyzed for purity by HPLC with both UV (200 to $400 \mathrm{~nm}$ ) and ELSD (Evaporative Light Scattering Detection) detection used. Purity of all compounds was $\geq 95 \%$. 


\section{General procedure 1. Synthesis of peracetylated $\beta$-S-propynyl glycosides.}

To a solution of the per-O-acetylated sugar (1.0 equiv.) in anhydrous $\mathrm{CH}_{3} \mathrm{CN}$ at rt was added thiourea (1.5 equiv.) and boron trifluoride diethyletherate (1.5 equiv.). The resulting mixture was refluxed ( $\sim 1 \mathrm{~h}$ ), full consumption of the sugar starting material was evidenced by TLC (1:1 EtOAc/hexane). The reaction mixture was cooled to rt, triethylamine (1.5 equiv.) and propargyl bromide (1.5 equiv.) added and the reaction stirred at rt until completion ( $\sim \mathrm{h}$ ), evidenced by TLC (1:1 EtOAc/hexane). The solvent was evaporated and the resulting syrup diluted with $\mathrm{CH}_{2} \mathrm{Cl}_{2}$, washed with $\mathrm{HCl} 5 \%(\times 1)$ and brine $(\times 2)$, aqueous phases were back extracted with $\mathrm{CH}_{2} \mathrm{Cl}_{2}(\times 2)$. The organic extracts were combined, dried with $\mathrm{MgSO}_{4}$, filtered and the solvent removed in vacuo. The crude mixture was purified by flash chromatography as detailed to afford pure glycosides $\mathbf{2}-\mathbf{4}$.

\section{General procedure 2. Dual synthesis of 5-iodo- and 5-H- 1,2,3-triazole benzenesulfonamide glycoconjugates. ${ }^{26}$}

A solution of peracetylated $\beta$-S-propynyl glycoside (1.0 equiv.) and 4-azidobenzene sulfonamide (1, 1.2 equiv.) in THF was prepared. CuI (1.2 equiv.) and DIPEA (1.2 equiv.) were added, followed by dropwise addition of a solution of NBS (1.2 equiv.) in THF. The reaction was stirred at rt overnight. The solvent was removed in vacuo leaving a brown residue. This crude material was redissolved in $\mathrm{CH}_{2} \mathrm{Cl}_{2}$, washed with $5 \% \mathrm{HCl}(\times 1)$ and brine $(\times 2)$, followed by back extraction of the aqueous extracts with $\mathrm{CH}_{2} \mathrm{Cl}_{2}(\times 2)$. The organic extracts were then combined, dried with $\mathrm{MgSO}_{4}$ and filtered. The solvent was removed in vacuo to produce a brown solid. Purification by flash chromatography, detailed below, afforded both the target 5-iodo substituted 5, 7, 9 and unsubstituted 6, 8, 10 1,2,3-triazole benzensulfonamide glycoconjugates. 


\section{General procedure 3. Oxidation of 1,2,3-triazole benzenesulfonamide glycoconjugates.}

A solution of the 1,2,3-triazole benzenesulfonamide glycoconjugate (1.0 equiv.) in anhydrous $\mathrm{CH}_{2} \mathrm{Cl}_{2}$ was prepared and cooled to $0{ }^{\circ} \mathrm{C}$. A solution of $m \mathrm{CPBA}$ (7.0 equiv) in anhydrous $\mathrm{CH}_{2} \mathrm{Cl}_{2}$ was added dropwise and the reaction allowed to warm to rt. Oxidation of the starting material was complete after $2 \mathrm{~h}$, with the reaction progress monitored by TLC. The reaction mixture was washed with $\mathrm{NaHCO}_{3}(\times 1)$ and brine $(\times 2)$, dried with $\mathrm{MgSO}_{4}$, filtered and the solvent then removed in vacuo. The crude product was purified by flash chromatography, described below, to afford target compounds $\mathbf{1 1} \mathbf{- 1 6}$.

\section{General procedure 4. Deprotection of glycoconjugates.}

Fully deprotected sugars of glycoconjugates were prepared by treating the corresponding acetylated precursors (1.0 equiv.) in dry $\mathrm{MeOH}$ at $0{ }^{\circ} \mathrm{C}$ with methanolic sodium methoxide (0.05 M final concentration; $\mathrm{pH}$ 12). The reaction was warmed to rt and left to stir until full deacetylation was evident by TLC $\left(\mathrm{CH}_{3} \mathrm{CN}: \mathrm{H}_{2} \mathrm{O}\right.$ 9:1; 30 min - overnight). Neutralization of the solution by Amberlite IR-120- $\mathrm{H}^{+}$ion-exchange resin, followed by filtration (the resin washed several times with methanol) and evaporation of the filtrate to dryness, afforded pure compounds $17-26$.

\section{General procedure 5. Synthesis of 5-substituted-1,2,3-triazole benzenesulfonamide glycoconjugates.}

A solution of 5-iodo-1,2,3-triazole benzenesulfonamide glycoconjugate (1.0 equiv.) and $\mathrm{Pd}\left(\mathrm{PPh}_{3}\right)_{4}$ (1.0 equiv.) in THF was prepared and stirred at rt under an inert nitrogen atmosphere. A second solution, comprising CuI (1.0 equiv.), triethylamine (1.0 equiv.) and propargyl alcohol (1.0 equiv.) in THF, was stirred under an inert nitrogen atmosphere at rt. 
After 30 min the two solutions were combined and the reaction stirred at $50{ }^{\circ} \mathrm{C}$ until complete consumption of the starting material was evidenced by TLC ( $30 \mathrm{~min})$. The reaction mixture was filtered through a pre-packed silica SPE cartridge and eluted with EtOAc. The solvent was removed from the crude product in vacuo, the residue redissolved in $\mathrm{CH}_{2} \mathrm{Cl}_{2}$ and washed with $\mathrm{HCl} 5 \%(\times 1)$ and brine $(\times 2)$. The aqueous extracts were back extracted with $\mathrm{CH}_{2} \mathrm{Cl}_{2}(\times 2)$. The organic extracts were combined, dried with $\mathrm{MgSO}_{4}$, filtered and the solvent removed in vacuo. The crude product was purified by flash chromatography as described to afford the substituted triazole derivatives $\mathbf{2 7}, \mathbf{2 8}$.

\section{p-Azidobenzene sulfonamide (1)}

Sulfanilamide (10.0 g, $58.1 \mathrm{mmol}, 1.0$ equiv.) was dissolved in $\mathrm{CH}_{3} \mathrm{CN}$ (300 mL) and the solution cooled to $0{ }^{\circ} \mathrm{C}$. tert-Butyl nitrite (t-BuONO) (10.3 mL, $86.6 \mathrm{mmol}, 1.5$ equiv.) was added dropwise followed by dropwise addition of azidotrimethylsilane $\left(\mathrm{TMSN}_{3}\right)(11.5 \mathrm{~mL}$, $86.6 \mathrm{mmol}, 1.5$ equiv.). The reaction mixture was stirred at rt and reaction progress monitored by TLC (1:1 EtOAc/hexane). After full conversion of the starting material the solvent was evaporated and the resulting syrup diluted with EtOAc $(100 \mathrm{~mL})$, washed with water $(\times 1)$ and brine $(\times 2)$. The aqueous extracts were combined and back extracted with EtOAc $(\times 2)$. The combined organic extracts were dried with $\mathrm{MgSO}_{4}$, filtered and the solvent removed in vacuo to produce an orange solid. The solid was redissolved in EtOAc $(150 \mathrm{~mL})$ and reprecipitated with the slow addition of hexane (350 mL) to afford the title compound as a pale yellow solid (9.33 g, $47.1 \mathrm{mmol}, 81 \%$ yield). ${ }^{1} \mathrm{H}$ NMR (500 MHz, $\left.\mathrm{CDCl}_{3}\right): \delta(\mathrm{ppm})=7.93(\mathrm{~d}, J=8.5 \mathrm{~Hz}$, 2H, $\mathrm{H}_{\text {arom. }}$ ); 7.15 (d, $J=8.5 \mathrm{~Hz}, 2 \mathrm{H}, \mathrm{H}_{\text {arom. }}$ ); 4.84 (s, 2H, SONH$H_{2}$ ), assignments were confirmed by ${ }^{1} \mathrm{H}-{ }^{1} \mathrm{H}$ gCOSY. LRMS $\left(\mathrm{ESI}^{+}\right): \mathrm{m} / \mathrm{z}=221[\mathrm{M}+\mathrm{Na}]^{+}$.

\section{2,3,4,6-Tetra- $O$-acetyl- $S$-propynyl-1-thio- $\beta$-D-glucopyranoside (2)}


The title compound 2 was prepared from commercially purchased per-O-acetylated $\beta$-Dglucose according to general procedure 1 and isolated as a clear oil (76\% yield) by flash chromatography (1:1 EtOAc/hexane). ${ }^{1} \mathrm{H}$ NMR (500 MHz, $\left.\mathrm{CDCl}_{3}\right): \delta(\mathrm{ppm})=5.26(\mathrm{t}, J=9.5$ Hz, 1H, H-3); 5.10 (t, $J=9.5$ Hz, 1H, H-4); 5.06 (t, $J=9.5$ Hz, 1H, H-2); 4.77 (d, $J=10.0 \mathrm{~Hz}$, 1H, H-1); 4.25 (dd, $J=12.0,4.5$ Hz, H-6a); 4.15 (dd, $J=12.5,2.0$ Hz, 1H, H-6b); 3.73 (ddd, $J$ = 10.0, 4.5, $2.0 \mathrm{~Hz}, 1 \mathrm{H}, \mathrm{H}-5) ; 3.58$ (dd, $J=16.5,2.5 \mathrm{~Hz}, 1 \mathrm{H}, \mathrm{SCHa}$ ); 3.29 (dd, $J=16.0,2.5$ $\mathrm{Hz}, 1 \mathrm{H}, \mathrm{SCHb}) ; 2.26(\mathrm{t}, J=2.5 \mathrm{~Hz}, 1 \mathrm{H}, \mathrm{C} \equiv \mathrm{CH}) ; 2.08,2.06,2.03,2.01\left(4 \times \mathrm{s}, 12 \mathrm{H}, \mathrm{OCOCH}_{3}\right)$, assignments were confirmed by ${ }^{1} \mathrm{H}-{ }^{1} \mathrm{H}$ gCOSY.${ }^{13} \mathrm{C}$ NMR $\left(125 \mathrm{Mz}, \mathrm{CDCl}_{3}\right): \delta(\mathrm{ppm})=170.8$, 170.4, 169.6, $169.5\left(\mathrm{OCOCH}_{3}\right) ; 82.3(\mathrm{C}-1) ; 78.9\left(\mathrm{CH}_{2} \mathrm{C} \equiv \mathrm{CH}\right) ; 76.2$ (C-5); 74.0 (C-3); 72.1 $\left(\mathrm{CH}_{2} \mathrm{C} \equiv \mathrm{CH}\right) ; 70.0$ (C-2); 68.5 (C-4); 62.2 (C-6); 20.9, 20.8, 20.8, $20.7\left(\mathrm{OCOCH}_{3}\right) ; 17.7$ $\left(\mathrm{CH}_{2} \mathrm{C} \equiv \mathrm{CH}\right)$, assignments were confirmed by ${ }^{1} \mathrm{H}^{13}{ }^{13} \mathrm{HSQC}$. LRMS $\left(\mathrm{ESI}^{+}\right): \mathrm{m} / \mathrm{z}=425[\mathrm{M}+$ $\mathrm{Na}]^{+}$. Analytical data is consistent with values reported in the literature. ${ }^{11}$

\section{2,3,4,6-Tetra- $O$-acetyl- $S$-propynyl-1-thio- $\beta$-D-galactopyranoside (3)}

The title compound $\mathbf{3}$ was prepared from commercially purchased per- $O$-acetylated $\beta$-Dgalactose according to general procedure 1 and isolated as a clear oil (82\% yield) by flash chromatography (1:1 EtOAc/hexane). ${ }^{1} \mathrm{H}$ NMR (500 MHz, $\left.\mathrm{CDCl}_{3}\right): \delta(\mathrm{ppm})=5.45(\mathrm{~d}, J=3.5$ Hz, 1H, H-4); 5.26 (t, $J=10.0 \mathrm{~Hz}, 1 \mathrm{H}, \mathrm{H}-2) ; 5.09$ (dd, $J=10.0,3.5 \mathrm{~Hz}, 1 \mathrm{H}, \mathrm{H}-3) ; 4.74$ (d, $J=$ 10.0 Hz, 1H, H-1); 4.19-4.08 (m, 2H, H-6a, H-6b); 3.96 (m, 1H, H-5); 3.57 (dd, $J=16.5,2.5$ $\mathrm{Hz}, 1 \mathrm{H}, \mathrm{SCHa}$ ); 3.31 (dd, $J=16.5,2.5 \mathrm{~Hz}, 1 \mathrm{H}, \mathrm{SCHb}) ; 2.26$ (t, $J=2.5 \mathrm{~Hz}, 1 \mathrm{H}, \mathrm{C} \equiv \mathrm{CH}) ; 2.16$, 2.07, 2.05, $1.99\left(4 \times \mathrm{s}, 12 \mathrm{H}, \mathrm{OCOCH}_{3}\right)$, assignments were confirmed by ${ }^{1} \mathrm{H}-{ }^{1} \mathrm{H}$ gCOSY. ${ }^{13} \mathrm{C}$ $\operatorname{NMR}\left(125 \mathrm{Mz}, \mathrm{CDCl}_{3}\right): \delta(\mathrm{ppm})=170.6,170.4,170.2,169.9\left(\mathrm{OCOCH}_{3}\right) ; 82.8(\mathrm{C}-1) ; 79.0$ $\left(\mathrm{CH}_{2} \mathrm{C} \equiv \mathrm{CH}\right) ; 74.8(\mathrm{C}-5) ; 72.1(\mathrm{C}-3) ; 72.0\left(\mathrm{CH}_{2} \mathrm{C} \equiv \mathrm{CH}\right) ; 67.5$ (C-4); 67.4 (C-2); 61.6 (C-6); 21.0, 20.9, 20.9, $20.8\left(\mathrm{OCOCH}_{3}\right) ; 17.7\left(\mathrm{CH}_{2} \mathrm{C} \equiv \mathrm{CH}\right)$, assignments were confirmed by ${ }^{1} \mathrm{H}_{-}{ }^{13} \mathrm{C}$ 
HSQC. LRMS $\left(\mathrm{ESI}^{+}\right): m / z=425[\mathrm{M}+\mathrm{Na}]^{+}$. Analytical data is consistent with values reported in the literature. ${ }^{11}$

\section{2,2',3,3',4',6,6'-Hepta-O-acetyl-S-propynyl-1-thio- $\beta$-maltoside (4)}

The title compound 5 was prepared from 1,2,2',3,3',4',6,6'-hepta-O-acetyl- $\beta$-maltose according to general procedure 1 and isolated as a white solid (37\% yield) by flash chromatography (1:1.2 EtOAc/hexane). $\mathrm{R}_{f}=0.48$ (1:1 EtOAc/hexane). ${ }^{1} \mathrm{H}$ NMR (500 MHz, $\left.\mathrm{CDCl}_{3}\right): \delta(\mathrm{ppm})=$ 5.35 (m, 1H, H-3); 5.27 (d, $\left.J=4.0 \mathrm{~Hz}, 1 \mathrm{H}, \mathrm{H}-1^{\prime}\right) ; 5.21$ (t, $\left.J=10.0 \mathrm{~Hz}, 1 \mathrm{H}, \mathrm{H}-3^{\prime}\right) ; 4.98$ (t, $J=$ $\left.9.5 \mathrm{~Hz}, 1 \mathrm{H}, \mathrm{H}-4^{\prime}\right) ; 4.97$ (d, $J=9.5 \mathrm{~Hz}, 1 \mathrm{H}, \mathrm{H}-1$ ); 4.87 (dd, $J=10.5,4.0 \mathrm{~Hz}, 1 \mathrm{H}, \mathrm{H}-2$ ); 4.78 (t, $J=9.5$ Hz, 1H, H-2); 4.39 (m, 1H, H-6a); 4.16 (m, 2H, H-6a', H-6b); 4.02 (m, 1H, H-6b'); 4.00 (m, 1H, H-5); 3.97 (m, 2H, H-5', H-4); 3.44 (br s, 2H, SCH $)$; 3.18 (br s, $1 \mathrm{H}, \mathrm{C} \equiv \mathrm{CH}$ ); 2.07, 2.02, 2.02, 1.99, 1.99, 1.98, $1.95\left(7 \times \mathrm{s}, 21 \mathrm{H}, \mathrm{OCOCH}_{3}\right)$, assignments were confirmed by ${ }^{1} \mathrm{H}-$ ${ }^{1} \mathrm{H}$ gCOSY. LRMS $\left(\mathrm{ESI}^{+}\right): \mathrm{m} / \mathrm{z}=708\left[\mathrm{M}+\mathrm{NH}_{4}\right]^{+}, 713[\mathrm{M}+\mathrm{Na}]^{+}$.

p-(4-\{[2',3',4',6'-Tetra-O-acetyl-ß-D-glucopyranosyl]thiomethyl\}-5-iodo-1-H-1,2,3-triazol1-yl)benzenesulfonamide (5) and

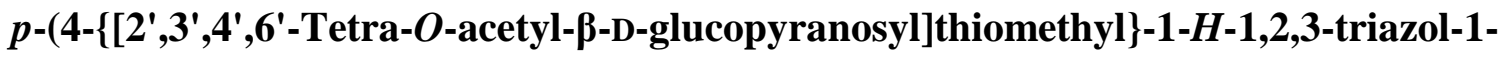

\section{yl)benzenesulfonamide (6)}

Title compounds $\mathbf{5}$ and $\mathbf{6}$ were prepared from azide $\mathbf{1}$ and alkyne $\mathbf{2}$ according to general procedure 2. Purification by flash chromatography (3:1 EtOAc/hexane) afforded compound 5 (43\%) and 6 (45\%) as light brown solids.

Compound 5: m.p. $=97-100{ }^{\circ} \mathrm{C} \cdot[\alpha]^{25} \mathrm{D}=-60(c=1.0$, chloroform $) .{ }^{1} \mathrm{H}$ NMR $(500 \mathrm{MHz}$, DMSO- $\left.d_{6}\right): \delta(\mathrm{ppm})=8.06,7.85\left(2 \times \mathrm{d}, J=8.5 \mathrm{~Hz}, 4 \mathrm{H}, \mathrm{H}_{\text {arom. }}\right) ; 7.58\left(\mathrm{~s}, 2 \mathrm{H}, \mathrm{NH}_{2}\right) ; 5.32(\mathrm{t}, J=$ 9.0 Hz, 1H, H-3'); 4.97 (t, J=10.0 Hz, 1H, H-4'); 4.96 (d, J=9.5 Hz, 1H, H-1'); 4.94 (t, $J=9.0$

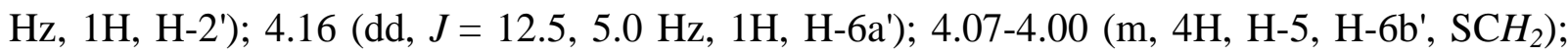


2.01, 2.00, 1.99, $1.95\left(4 \times \mathrm{s}, 12 \mathrm{H}, \mathrm{OCOCH}_{3}\right)$, assignments were confirmed by ${ }^{1} \mathrm{H}-{ }^{1} \mathrm{H}$ gCOSY. ${ }^{13} \mathrm{C}$ NMR (500 MHz; DMSO): $\delta(\mathrm{ppm})=170.0,169.5,169.2,169.0\left(\mathrm{OCOCH}_{3}\right) ; 148.4$ $\left(\mathrm{C}_{\text {arom. }}\right) ; 145.3$ ( $\left.\mathrm{C}_{\text {triazole }}\right) ; 139.0$ ( $\left.\mathrm{C}_{\text {arom. }}\right) ; 127.0,127.0,126.6,126.6\left(\mathrm{CH}_{\text {arom. }}\right) ; 85.2\left(\mathrm{CI}_{\text {triazole }}\right)$; 81.1 (C-1'); 74.4 (C-5'); 72.9 (C-3'); 69.6 (C-2' or C-4'); 68.1 (C-4' or C-2'); 61.9 (C-6'); 23.2 $\left(\mathrm{SCH}_{2}\right)$; 20.5, 20.4, 20.3, $20.2\left(\mathrm{OCOCH}_{3}\right)$, assignments were confirmed by ${ }^{1} \mathrm{H}-{ }^{13} \mathrm{C}$ HSQC. LRMS $\left(\mathrm{ESI}^{+}\right): \mathrm{m} / \mathrm{z}=727[\mathrm{M}+\mathrm{H}]^{+}, 749[\mathrm{M}+\mathrm{Na}]^{+}$. HRMS: Calcd for $\mathrm{C}_{23} \mathrm{H}_{28} \mathrm{IN}_{4} \mathrm{O}_{11} \mathrm{~S}_{2}$ 727.0235, Found 727.0216.

Compound 6: m.p. $=91-95{ }^{\circ} \mathrm{C} .[\alpha]^{25}{ }_{\mathrm{D}}=-44(c=1.0$, chloroform $) .{ }^{1} \mathrm{H}$ NMR $(500 \mathrm{MHz}$, DMSO- $\left.d_{6}\right): \delta(\mathrm{ppm})=8.75\left(\mathrm{~s}, 1 \mathrm{H}, \mathrm{CH}_{\text {triazole }}\right) ; 8.10,8.02\left(2 \times \mathrm{d}, J=8.5 \mathrm{~Hz}, 4 \mathrm{H}, \mathrm{H}_{\text {arom }}\right) ; 7.51$ (s, 2H, $\mathrm{NH}_{2}$ ); 5.31 (t, $\left.J=9.5 \mathrm{~Hz}, 1 \mathrm{H}, \mathrm{H}-3^{\prime}\right) ; 4.98$ (d, $\left.J=10.0 \mathrm{~Hz}, 1 \mathrm{H}, \mathrm{H}-1^{\prime}\right) ; 4.97$ (t, $J=9.5 \mathrm{~Hz}$, 1H, H-2'); 4.93 (t, $J=10.0$ Hz, 1H, H-4'); 4.16 (dd, $J=12.5,5.0$ Hz, 1H, H-6a'); 4.05-4.01 (m, 4H, H-5, H-6b', SCH ); 1.98, 1.97, 1.95 (3 × s, 12H, OCOCH $\mathrm{O}_{3}$, assignments were confirmed by ${ }^{1} \mathrm{H}-{ }^{1} \mathrm{H}$ gCOSY. ${ }^{13} \mathrm{C}$ NMR (500 MHz; DMSO): $\delta(\mathrm{ppm})=170.0,169.5,169.2,169.1$ $\left(\mathrm{OCOCH}_{3}\right) ; 148.4\left(\mathrm{C}_{\text {triazole }}\right) ; 143.8,138.6\left(\mathrm{C}_{\text {arom. }}\right) ; 127.4,127.4\left(\mathrm{CH}_{\text {arom. }}\right) ; 121.8\left(\mathrm{CH}_{\text {triazole }}\right)$; 120.2, $120.2\left(\mathrm{CH}_{\text {arom. }}\right)$; 81.0 (C-1'); 74.5 (C-5'); 72.9 (C-3'); 69.5 (C-2' or C-4'); 68.0 (C-4' or C2'); 61.8 (C-6'); $23.2\left(\mathrm{SCH}_{2}\right) ; 20.4,20.3,20.3,20.2\left(\mathrm{OCOCH}_{3}\right)$, assignments were confirmed by ${ }^{1} \mathrm{H}^{-13} \mathrm{C}$ HSQC. LRMS $\left(\mathrm{ESI}^{+}\right): m / z=601[\mathrm{M}+\mathrm{H}]^{+}, 623[\mathrm{M}+\mathrm{Na}]^{+}$. HRMS: Calcd for $\mathrm{C}_{23} \mathrm{H}_{29} \mathrm{~N}_{4} \mathrm{O}_{11} \mathrm{~S}_{2}$ 601.1269, Found 601.1276. Analytical data is consistent with values reported in the literature. ${ }^{18}$

p-(4-\{[2',3',4',6'-Tetra-O-acetyl- $\beta$-D-galactopyranosyl]thiomethyl $\}-5-i o d o-1-H-1,2,3-$ triazol-1-yl)benzenesulfonamide (7) and p-(4-\{[2',3',4',6'-Tetra-O-acetyl- $\beta$-D-galactopyranosyl]thiomethyl\}-1-H-1,2,3-triazol-1yl)benzenesulfonamide (8) 
Title compounds $\mathbf{7}$ and $\mathbf{8}$ were prepared from azide $\mathbf{1}$ and alkyne $\mathbf{3}$ according to general procedure 2. Purification by flash chromatography (3:1 EtOAc/hexane) afforded compound 7 (45\%) and 8 (47\%) as light brown solids.

Compound 7: m.p. $=98-99{ }^{\circ} \mathrm{C} \cdot[\alpha]^{25} \mathrm{D}=-37(c=1.0$, chloroform $) .{ }^{1} \mathrm{H}$ NMR $(500 \mathrm{MHz}$, DMSO- $\left.d_{6}\right): \delta(\mathrm{ppm})=8.07,7.84\left(2 \times \mathrm{d}, J=8.5 \mathrm{~Hz}, 4 \mathrm{H}, \mathrm{H}_{\text {arom. }}\right) ; 7.59\left(\mathrm{~s}, 2 \mathrm{H}, \mathrm{NH}_{2}\right) ; 5.32(\mathrm{~d}, J=$ $\left.3.0 \mathrm{~Hz}, 1 \mathrm{H}, \mathrm{H}-4^{\prime}\right) ; 5.22$ (dd, $\left.J=10.0,3.5 \mathrm{~Hz}, 1 \mathrm{H}, \mathrm{H}-3^{\prime}\right) ; 5.03$ (t, $J=10.0 \mathrm{~Hz}, 1 \mathrm{H}, \mathrm{H}-2^{\prime}$ ); 4.90 (d, $J=10.0$ Hz, 1H, H-1'); 4.22 (m, 1H, H-5'); 4.06-3.98 (m, 4H, H-6a', H-6b', SCH $)$; 2.13, 2.01, 2.00, $1.92\left(4 \times \mathrm{s}, 12 \mathrm{H}\right.$, OCOCH$\left.{ }_{3}\right)$, assignments were confirmed by ${ }^{1} \mathrm{H}-{ }^{1} \mathrm{H}$ gCOSY. ${ }^{13} \mathrm{C}$ NMR (500 MHz; DMSO): $\delta(\mathrm{ppm})=170.1,170.0,169.5,169.4\left(\mathrm{OCOCH}_{3}\right) ; 148.5\left(\mathrm{C}_{\text {arom. }}\right) ; 145.4$ ( $\left.\mathrm{C}_{\text {triazole }}\right)$; 139.1 ( $\left.\mathrm{C}_{\text {arom. }}\right)$; 127.1, 126.7 ( $\left.\mathrm{CH}_{\text {arom. }}\right)$; 85.2 (CI $\left.\mathrm{I}_{\text {riazole }}\right)$; 81.9 (C-1'); 73.5 (C-5'); 71.0 (C-3'); 67.5 (C-4'); 67.3 (C-2'); $61.3\left(\mathrm{C}^{\prime}{ }^{\prime}\right) ; 24.3\left(\mathrm{SCH}_{2}\right) ; 20.6,20.6,20.5,20.4\left(\mathrm{OCOCH}_{3}\right)$, assignments were confirmed by ${ }^{1} \mathrm{H}^{-13} \mathrm{C}$ HSQC. LRMS $\left(\mathrm{ESI}^{+}\right): \mathrm{m} / \mathrm{z}=727[\mathrm{M}+\mathrm{H}]^{+}, 749[\mathrm{M}+$ $\mathrm{Na}]^{+}$. HRMS: Calcd for $\mathrm{C}_{23} \mathrm{H}_{27} \mathrm{IN}_{4} \mathrm{O}_{11} \mathrm{~S}_{2} \mathrm{Na}$ 749.0055, Found 749.0047.

Compound 8: m.p. $=189-190{ }^{\circ} \mathrm{C} .[\alpha]^{25}=-34(c=1.0$, chloroform $) .{ }^{1} \mathrm{H}$ NMR $(500 \mathrm{MHz}$, DMSO- $\left.d_{6}\right): \delta(\mathrm{ppm})=8.74\left(\mathrm{~s}, 1 \mathrm{H}, \mathrm{CH}_{\text {triazole }}\right) ; 8.11,8.02\left(2 \times \mathrm{d}, J=8.5 \mathrm{~Hz}, 4 \mathrm{H}, \mathrm{H}_{\text {arom }}\right) ; 7.51$ (s, 2H, $\mathrm{NH}_{2}$ ); 5.32 (d, $J=3.5 \mathrm{~Hz}, 1 \mathrm{H}, \mathrm{H}-4$ '); 5.22 (dd, $J=10.0,3.5 \mathrm{~Hz}, 1 \mathrm{H}, \mathrm{H}-3$ '); 5.04 (t, $J=10.0$ Hz, 1H, H-2'); 4.93 (d, $\left.J=10.0 \mathrm{~Hz}, 1 \mathrm{H}, \mathrm{H}-1^{\prime}\right) ; 4.25$ (m, 1H, H-6a'); 4.08 (d, $J=14.0 \mathrm{~Hz}, 1 \mathrm{H}$, SCHa); 4.04-4.01 (m, 3H, H-5, H-6b' SCHb); 2.13, 2.00, 1.97, 1.92 (4 × s, 12H, $\mathrm{OCOCH}_{3}$ ), assignments were confirmed by ${ }^{1} \mathrm{H}-{ }^{1} \mathrm{H}$ gCOSY. ${ }^{13} \mathrm{C}$ NMR (500 MHz; DMSO): $\delta(\mathrm{ppm})=$ 169.9, 169.8, 169.4, $169.3\left(\mathrm{OCOCH}_{3}\right) ; 145.0$ (C $\left.\mathrm{C}_{\text {triazole }}\right) ; 143.8,138.5\left(\mathrm{C}_{\text {arom. }}\right)$; 127.4, 127.4 ( $\left.\mathrm{CH}_{\text {arom. }}\right)$; 121.7 ( $\left.\mathrm{CH}_{\text {triazole }}\right) ; 120.2,120.2\left(\mathrm{CH}_{\text {arom. }}\right)$; 81.8 (C-1'); 73.4 (C-5'); 70.9 (C-3'); 67.5 (C-4'); 67.2 (C-2'); 61.4 (C-6'); $23.5\left(\mathrm{SCH}_{2}\right) ; 20.4,20.4$, 20.3, $20.3\left(\mathrm{OCOCH}_{3}\right)$, assignments were confirmed by ${ }^{1} \mathrm{H}^{13}{ }^{13} \mathrm{C}$ HSQC. LRMS $\left(\mathrm{ESI}^{+}\right): \mathrm{m} / \mathrm{z}=601[\mathrm{M}+\mathrm{H}]^{+}, 623[\mathrm{M}+\mathrm{Na}]^{+}$. HRMS: Calcd for $\mathrm{C}_{23} \mathrm{H}_{29} \mathrm{~N}_{4} \mathrm{O}_{11} \mathrm{~S}_{2} 601.1269$, Found 601.1252. Analytical data is consistent with values reported in the literature. ${ }^{18}$ 


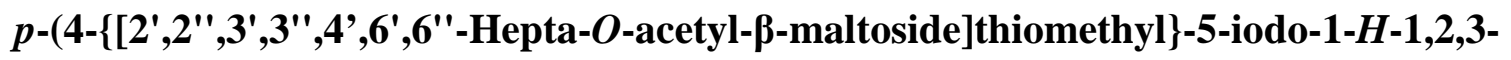
triazol-1-yl)benzenesulfonamide (9) and p-(4-\{[2',2' ',3',3' ',4',6',6"'-Hepta-O-acetyl- $\beta$-maltoside]thiomethyl\}-1-H-1,2,3-triazol-1yl)benzenesulfonamide (10)

Compounds $\mathbf{9}$ and $\mathbf{1 0}$ were prepared from azide $\mathbf{1}$ and alkyne $\mathbf{4}$ according to general procedure 2. Purification by flash chromatography (1:1 then 2:1 EtOAc/hexane) afforded compound 9 (35\%) and 10 (47\%) as light yellow solids. These compounds were carried through to oxidation.

Compound 9: $\mathrm{R}_{f}=0.36$ (2:1 AcOEt/hexane). ${ }^{1} \mathrm{H}$ NMR (500 MHz, DMSO- $\left.d_{6}\right): \delta(\mathrm{ppm})=8.07$, 7.85 (2 × d, $\left.J=8.5 \mathrm{~Hz}, 4 \mathrm{H}, \mathrm{H}_{\text {arom. }}\right) ; 7.58$ (s, 2H, $\mathrm{NH}_{2}$ ); 5.35 (m, 1H, H-3'); 5.29 (d, $J=3.5 \mathrm{~Hz}$, 1H, H-1"); 5.23 (t, $J=10.0$ Hz, 1H, H-3"); 4.99 (t, $J=9.5$ Hz, 1H, H-4"); 4.95 (d, $J=10.0$ Hz , 1H, H-1'); 4.87 (dd, $J=10.5,3.5$ Hz, 1H, H-2"); 4.80 (t, $J=9.5$ Hz, 1H, H-2'); 4.42 (m, 1H, H6a'); 4.16 (m, 2H, H-6a", H-6b'); 4.03 (m, 1H, H-6b"); 3.97 (m, 5H, H-4', H-5', H-5', SCH ); 2.09, 2.02, 2.01, 1.99, 1.98, 1.96, $1.95\left(7 \times \mathrm{s}, 21 \mathrm{H}, \mathrm{OCOCH}_{3}\right)$, assignments were confirmed by ${ }^{1} \mathrm{H}-{ }^{1} \mathrm{H}$ gCOSY. LRMS $\left(\mathrm{ESI}^{+}\right): \mathrm{m} / \mathrm{z}=1016[\mathrm{M}+\mathrm{H}]^{+}, \mathrm{m} / \mathrm{z}=1038[\mathrm{M}+\mathrm{Na}]^{+}$.

Compound 10: $\mathrm{R}_{f}=0.25$ (2:1 AcOEt/hexane). ${ }^{1} \mathrm{H}$ NMR (500 MHz, DMSO- $\left.d_{6}\right): \delta(\mathrm{ppm})=8.72$ (s, $\left.1 \mathrm{H}, \mathrm{C} H_{\text {triazole }}\right) ; 8.11,8.03\left(2 \times \mathrm{d}, J=8.5 \mathrm{~Hz}, 4 \mathrm{H}, \mathrm{H}_{\text {arom. }}\right) ; 7.51\left(\mathrm{~s}, 2 \mathrm{H}, \mathrm{NH} H_{2}\right) ; 5.35$ (t, $J=8.5$ Hz, 1H, H-3'); 5.28 (d, $J=3.5$ Hz, 1H, H-1"); 5.22 (t, $J=10.0 \mathrm{~Hz}, 1 \mathrm{H}, \mathrm{H}-3 ") ; 4.98$ (t, $J=10.0$ Hz, 1H, H-4"); 4.97 (d, $J=10.0$ Hz , 1H, H-1'); 4.87 (dd, $J=11.0,4.0$ Hz, 1H, H-2"); 4.81 (t, $J$ = $\left.10.0 \mathrm{~Hz}, 1 \mathrm{H}, \mathrm{H}-2^{\prime}\right) ; 4.39$ (dd, $\left.J=12.0,1.5 \mathrm{~Hz}, 1 \mathrm{H}, \mathrm{H}-6 \mathrm{a}^{\prime}\right) ; 4.15$ (m, 2H, H-6a", H-6b'); 4.07

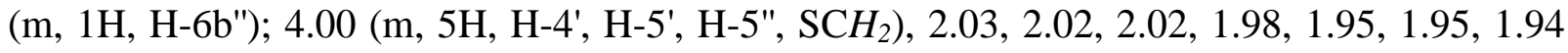
$\left(7 \times \mathrm{s}, 21 \mathrm{H}, \mathrm{OCOCH}_{3}\right)$, assignments were confirmed by ${ }^{1} \mathrm{H}-{ }^{1} \mathrm{H}$ gCOSY. LRMS $\left(\mathrm{ESI}^{+}\right): \mathrm{m} / \mathrm{z}=$ $890[\mathrm{M}+\mathrm{H}]^{+}, m / z=912[\mathrm{M}+\mathrm{Na}]^{+}$. 


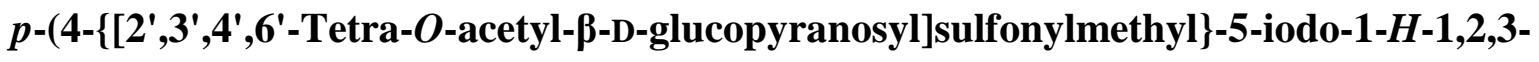
triazol-1-yl)benzenesulfonamide (11)

The title compound $\mathbf{1 1}$ was prepared from compound $\mathbf{5}$ according to the general procedure 3 . Purification by flash chromatography (3:1 EtOAc/hexane) afforded compound 11 (78\%) as a white solid. m.p. $=234-236{ }^{\circ} \mathrm{C} .[\alpha]^{25}{ }_{\mathrm{D}}=-86(c=1.0$, chloroform $) .{ }^{1} \mathrm{H}$ NMR $(500 \mathrm{MHz}$, DMSO- $\left.d_{6}\right): \delta(\mathrm{ppm})=8.09,7.87\left(2 \times \mathrm{d}, J=8.5 \mathrm{~Hz}, 4 \mathrm{H}, \mathrm{H}_{\text {arom. }}\right) ; 7.60\left(\mathrm{~s}, 2 \mathrm{H}, \mathrm{NH}_{2}\right) ; 5.44(\mathrm{~m}$, 2H, H-2', H-3'); 5.19 (d, $J=9.5$ Hz, 1H, H-1'); 5.07 (t, $J=9.5 \mathrm{~Hz}, 1 \mathrm{H}, \mathrm{H}-4$ '); 4.74 (d, $J=15.0$ Hz, 1H, SCHa); 4.66 (d, J = 15.0 Hz, 1H, SCHb); 4.26-4.21 (m, 3H, H-5', H-6a', H-6b'); 2.04, 2.01, $1.96\left(3 \times \mathrm{s}, 12 \mathrm{H}, \mathrm{OCOCH}_{3}\right)$, assignments were confirmed by ${ }^{1} \mathrm{H}-{ }^{1} \mathrm{H}$ gCOSY. ${ }^{13} \mathrm{C}$ NMR (500 MHz; DMSO): $\delta(\mathrm{ppm})=170.1,169.5,169.2,168.6\left(\mathrm{OCOCH}_{3}\right) ; 145.5\left(\mathrm{C}_{\text {arom. }}\right) ; 140.4$ ( $\left.\mathrm{C}_{\text {triazole }}\right)$; 138.9 ( $\left.\mathrm{C}_{\text {arom. }}\right) ; 127.1,127.1,126.8,126.8\left(\mathrm{CH}_{\text {arom. }}\right) ; 89.4\left(\mathrm{CI}_{\text {triazole }}\right) ; 85.6(\mathrm{C}-1)$; 75.1 (C-5'); 72.6 (C-3'); 67.3 (C-4'); 65.8 (C-2'); 61.3 (C-6'); $47.3\left(\mathrm{SCH}_{2}\right) ; 20.6,20.3,20.3,20.2$ $\left(\mathrm{OCOCH}_{3}\right)$, assignments were confirmed by ${ }^{1} \mathrm{H}_{-}{ }^{13} \mathrm{C}$ HSQC. LRMS $\left(\mathrm{ESI}^{+}\right): \mathrm{m} / \mathrm{z}=759[\mathrm{M}+$ $\mathrm{H}]^{+}, 776\left[\mathrm{M}+\mathrm{NH}_{4}\right]^{+}, 781[\mathrm{M}+\mathrm{Na}]^{+}$. HRMS: Calcd for $\mathrm{C}_{23} \mathrm{H}_{28} \mathrm{IN}_{4} \mathrm{O}_{13} \mathrm{~S}_{2}$ 759.0133, Found 759.0104.

p-(4-\{[2',3',4',6'-Tetra-O-acetyl- $\beta$-D-glucopyranosyl]sulfonylmethyl\}-1-H-1,2,3-triazol-1-

\section{yl)benzenesulfonamide (12)}

The title compound $\mathbf{1 2}$ was prepared from compound $\mathbf{6}$ according to the general procedure 3. Purification by flash chromatography (3:1 EtOAc/hexane) afforded the title compound 12 (83\% yield) as a white solid. ${ }^{1} \mathrm{H}$ NMR (500 MHz, DMSO- $\left.d_{6}\right): \delta(\mathrm{ppm})=8.91(\mathrm{~s}, 1 \mathrm{H}$, $\left.\mathrm{CH}_{\text {triazole }}\right) ; 8.17,8.05$ (2 × d, $J=8.5 \mathrm{~Hz}, 4 \mathrm{H}, \mathrm{H}_{\text {arom. }}$ ); 7.53 (s, 2H, $\left.\mathrm{NH}_{2}\right) ; 5.41$ (m, 2H, H-2', H3'); 5.18 (d, $\left.J=9.5 \mathrm{~Hz}, 1 \mathrm{H}, \mathrm{H}-1^{\prime}\right) ; 5.03$ (t, $J=9.5 \mathrm{~Hz}, 1 \mathrm{H}, \mathrm{H}-4$ '); 4.82 (d, $J=15.0 \mathrm{~Hz}, 1 \mathrm{H}$, SCHa); 4.76 (d, $J=15.0$ Hz, 1H, SCHb); 4.26-4.21 (m, 3H, H-5', H-6a', H-6b'); 2.02, 2.01, 1.95, $1.94(4 \times \mathrm{s}, 12 \mathrm{H}$, OCOCH$)$, assignments were confirmed by ${ }^{1} \mathrm{H}-{ }^{1} \mathrm{H}$ gCOSY.${ }^{13} \mathrm{C}$ NMR 
(500 MHz; DMSO): $\delta(\mathrm{ppm})=170.0,169.5,169.1,168.5\left(\mathrm{OCOCH}_{3}\right) ; 144.1\left(\mathrm{C}_{\text {triazole }}\right) ; 138.3$, 135.5 (C $\left.\mathrm{C}_{\text {arom. }}\right)$; 127.5, 127.5 ( $\left.\mathrm{CH}_{\text {arom. }}\right)$; $124.2\left(\mathrm{CH}_{\text {triazole }}\right) ; 120.5,120.5\left(\mathrm{CH}_{\text {arom. }}\right)$; 84.9 (C-1'); 74.9 (C-5'); 72.5 (C-3'); 67.2 (C-4'); 65.7 (C-2'); 61.4 (C-6'); $47.0\left(\mathrm{SCH}_{2}\right) ; 20.5,20.3,20.2$, $20.1\left(\mathrm{OCOCH}_{3}\right)$, assignments were confirmed by ${ }^{1} \mathrm{H}^{-13} \mathrm{C}$ HSQC. LRMS $\left(\mathrm{ESI}^{+}\right): \mathrm{m} / \mathrm{z}=655$ [M $+\mathrm{Na}]^{+}$. HRMS: Calcd for $\mathrm{C}_{23} \mathrm{H}_{28} \mathrm{~N}_{4} \mathrm{O}_{13} \mathrm{~S}_{2} \mathrm{Na}$ 655.0987, Found 655.0966. Analytical data is consistent with values reported in the literature. ${ }^{18}$

p-(4-\{[2',3',4',6'-Tetra-O-acetyl- $\beta$-D-galactopyranosyl]sulfonylmethyl\}-5-iodo-1- $H-1,2,3-$ triazol-1-yl)benzenesulfonamide (13)

The title compound $\mathbf{1 3}$ was prepared from compound $\mathbf{7}$ according to the general procedure 3 . Purification by flash chromatography (3:1 EtOAc/hexane) afforded the title compound $\mathbf{1 3}$ (78\% yield) as a white foam. ${ }^{1} \mathrm{H}$ NMR (500 MHz, DMSO- $\left.d_{6}\right): \delta(\mathrm{ppm})=8.09,7.88(2 \times \mathrm{d}, J=$ $8.5 \mathrm{~Hz}, 2 \mathrm{H}, \mathrm{H}_{\text {arom. }}$ ); 7.60 (s, 2H, $\mathrm{NH}_{2}$ ); 5.55 (t, $\left.J=9.5 \mathrm{~Hz}, 1 \mathrm{H}, \mathrm{H}-2^{\prime}\right) ; 5.38$ (m, 2H, H-3', H-4'); 5.16 (d, $\left.J=9.5 \mathrm{~Hz}, 1 \mathrm{H}, \mathrm{H}-1^{\prime}\right) ; 4.78$ (d, $J=14.5 \mathrm{~Hz}, 1 \mathrm{H}, \mathrm{SCHa}$ ); 4.59 (d, $J=14.5 \mathrm{~Hz}, 1 \mathrm{H}$, SCHb); 4.46 (br t, $J=6.0 \mathrm{~Hz}, 1 \mathrm{H}, \mathrm{H}-5^{\prime}$ ); 4.23 (dd, $J=11.5,7.0 \mathrm{~Hz}, 1 \mathrm{H}, \mathrm{H}-6 \mathrm{a}$ ); 4.12 (dd, $J=$ 11.5, $5.5 \mathrm{~Hz}, 1 \mathrm{H}, \mathrm{H}-6 \mathrm{~b})$; 2.17, 2.01, 1.97, 1.94 (4 × s, 3H, OCOCH$H_{3}$, assignments were

confirmed by ${ }^{1} \mathrm{H}-{ }^{1} \mathrm{H}$ gCOSY. ${ }^{13} \mathrm{C}$ NMR (500 MHz; DMSO): $\delta(\mathrm{ppm})=169.9,169.9,169.3$, $168.5\left(\mathrm{OCOCH}_{3}\right) ; 145.5$ ( $\left.\mathrm{C}_{\text {triazole }}\right) ; 140.5,138.8$ (C $\left.\mathrm{C}_{\text {arom. }}\right)$; 127.1, 127.1, 126.7, $126.7\left(\mathrm{CH}_{\text {arom. }}\right)$; 89.4 (CI $\left.\mathrm{I}_{\text {triazole }}\right)$; 85.7 (C-1'); 74.5 (C-5'); $70.6\left(\mathrm{C}-3^{\prime}\right) ; 67.1$ (C-4'); $62.9\left(\mathrm{C}-2^{\prime}\right) ; 61.0\left(\mathrm{C}-6^{\prime}\right) ; 47.4$ $\left(\mathrm{SCH}_{2}\right)$; 20.5, 20.4, 20.3, $20.2\left(\mathrm{OCOCH}_{3}\right)$, assignments were confirmed by ${ }^{1} \mathrm{H}-{ }^{13} \mathrm{C}$ HSQC. LRMS $\left(\mathrm{ESI}^{+}\right): m / z=759[\mathrm{M}+\mathrm{H}]^{+}, 781[\mathrm{M}+\mathrm{Na}]^{+}$. HRMS: Calcd for $\mathrm{C}_{23} \mathrm{H}_{28} \mathrm{IN}_{4} \mathrm{O}_{13} \mathrm{~S}_{2}$ 759.0133, Found 759.0119.

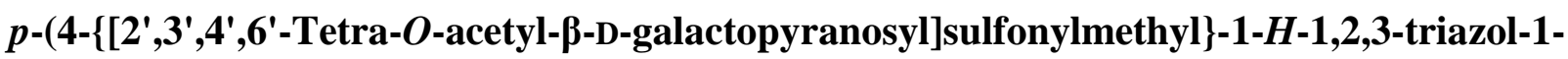
yl)benzenesulfonamide (14) 
The title compound $\mathbf{1 4}$ was prepared from compound $\mathbf{8}$ according to the general procedure 3 . Purification by flash chromatography (3:1 EtOAc/hexane) afforded the title compound 14 (82\% yield) as a white solid. m.p. $=206-208{ }^{\circ} \mathrm{C} .[\alpha]^{25}{ }_{\mathrm{D}}=-17\left(c=1.0\right.$, chloroform). ${ }^{1} \mathrm{H}$ NMR (500 MHz, DMSO-d $\left.)_{6}\right): \delta(\mathrm{ppm})=8.91\left(\mathrm{~s}, 1 \mathrm{H}, \mathrm{CH}_{\text {triazole }}\right) ; 8.16\left(2 \times \mathrm{d}, J=8.5 \mathrm{~Hz}, 4 \mathrm{H}, \mathrm{H}_{\text {arom. }}\right)$; 7.53 (s, 2H, NH $H_{2}$ ); 5.52 (t, $J=10.0 \mathrm{~Hz}, 1 \mathrm{H}, \mathrm{H}-2$ '); 5.37 (d, $J=3.5 \mathrm{~Hz}, 1 \mathrm{H}, \mathrm{H}-4$ '); 5.34 (dd, $J=$ 10.0, $\left.3.5 \mathrm{~Hz}, 1 \mathrm{H}, \mathrm{H}-3^{\prime}\right) ; 5.12$ (d, $\left.J=10.0 \mathrm{~Hz}, 1 \mathrm{H}, \mathrm{H}-1^{\prime}\right) ; 4.84$ (d, $J=14.5 \mathrm{~Hz}, 1 \mathrm{H}, \mathrm{SCHa}$ ); 4.73 (d, $J=15.0 \mathrm{~Hz}, 1 \mathrm{H}, \mathrm{SCHb}$ ); 4.45 (br t, $J=6.0 \mathrm{~Hz}, 1 \mathrm{H}, \mathrm{H}-5$ '); 4.21 (dd, $J=11.5,7.0 \mathrm{~Hz}, 1 \mathrm{H}, \mathrm{H}-$ $\left.6 a^{\prime}\right) ; 4.10$ (dd, $\left.J=11.5,5.0 \mathrm{~Hz}, 1 \mathrm{H}, \mathrm{H}-6 \mathrm{~b}\right) ; 2.16,2.02,1.95,1.93\left(4 \times \mathrm{s}, 12 \mathrm{H}, \mathrm{OCOCH}_{3}\right)$, assignments were confirmed by ${ }^{1} \mathrm{H}-{ }^{1} \mathrm{H}$ gCOSY. ${ }^{13} \mathrm{C}$ NMR (500 MHz; DMSO): $\delta$ (ppm) $=$ 169.9, 169.8, 169.4, $168.5\left(\mathrm{OCOCH}_{3}\right) ; 144.1$ (C $\left.\mathrm{C}_{\text {triazole }}\right) ; 138.3,135.6$ (C $\left.\mathrm{C}_{\text {arom. }}\right)$; 127.5, 127.5 $\left(\mathrm{CH}_{\text {arom. }}\right) ; 124.2\left(\mathrm{CH}_{\text {triazole }}\right) ; 120.5,120.5\left(\mathrm{CH}_{\text {arom. }}\right) ; 85.0$ (C-1'); 74.4 (C-5'); 70.6 (C-3'); 67.1 (C-4'); 62.8 (C-2'); $61.3\left(\mathrm{C}-6^{\prime}\right) ; 47.1\left(\mathrm{SCH}_{2}\right) ; 20.5,20.4$, 20.3, $20.2\left(\mathrm{OCOCH}_{3}\right)$, assignments were confirmed by ${ }^{1} \mathrm{H}_{-}{ }^{13} \mathrm{C}$ HSQC. LRMS $\left(\mathrm{ESI}^{+}\right): \mathrm{m} / \mathrm{z}=655[\mathrm{M}+\mathrm{Na}]^{+}$. HRMS: Calcd for $\mathrm{C}_{23} \mathrm{H}_{28} \mathrm{~N}_{4} \mathrm{O}_{13} \mathrm{~S}_{2} \mathrm{Na}$ 655.0987, Found 655.0962. Analytical data is consistent with values reported in the literature. ${ }^{18}$

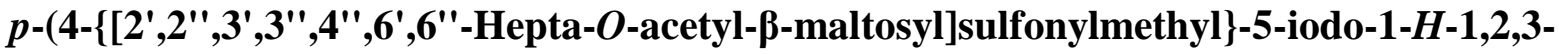

\section{triazol-1-yl)benzenesulfonamide (15)}

The title compound $\mathbf{1 5}$ was prepared from compound $\mathbf{9}$ according to the general procedure 3 . Purification by flash chromatography (2:1 EtOAc/hexane) afforded the title compound 15 (80\% yield) as a white solid. m.p. $=112-115{ }^{\circ} \mathrm{C} .[\alpha]^{25}{ }_{\mathrm{D}}=+25\left(c=1.0\right.$, chloroform). ${ }^{1} \mathrm{H}$ NMR (500 MHz, DMSO- $\left.d_{6}\right): \delta(\mathrm{ppm})=8.09,7.88\left(2 \times \mathrm{d}, J=9.0 \mathrm{~Hz}, 4 \mathrm{H}, \mathrm{H}_{\text {arom. }}\right) ; 7.60$ (s, $\left.2 \mathrm{H}, \mathrm{NH}_{2}\right)$; 5.46 (t, $\left.J=9.0 \mathrm{~Hz}, 1 \mathrm{H}, \mathrm{H}-3^{\prime}\right) ; 5.33$ (d, $J=2.0 \mathrm{~Hz}, 1 \mathrm{H}, \mathrm{H}-1$ "); 5.30 (t, $J=9.0 \mathrm{~Hz}, 1 \mathrm{H}, \mathrm{H}-2$ '); 5.24 (t, $J=10.0 \mathrm{~Hz}, 1 \mathrm{H}, \mathrm{H}-3 ") ; 5.16$ (d, $J=10.0 \mathrm{~Hz}, 1 \mathrm{H}, \mathrm{H}-1$ '); 5.01 (t, $J=10.0 \mathrm{~Hz}, 1 \mathrm{H}, \mathrm{H}-4 ")$; 4.90 (dd, $J=11.0,4.0 \mathrm{~Hz}, 1 \mathrm{H}, \mathrm{H}-2 ") ; 4.70$ (d, $J=15.0 \mathrm{~Hz}, 1 \mathrm{H}, \mathrm{SCH})$ ); 4.62 (d, $J=15.0 \mathrm{~Hz}, 1 \mathrm{H}$, 
SCHH); 4.59 (m, 1H, H-6a'); 4.28 (dd, $J=13.0,5.0$ Hz, 1H, H-6b'); 4.22 (m, 1H, H-5'); 4.19 (dd, $J=12.5,4.5$ Hz, 1H, H-6a"); 4.10 (t, $J=9.0$ Hz, 1H, H-4'); 4.06 (m, 1H, H-6b"); 4.02 (m, 1H, H-5"); 2.10, 2.03, 2.00, 1.99, 1.97, 1.96, $1.93\left(7 \times \mathrm{s}, 21 \mathrm{H}, \mathrm{COCH}_{3}\right)$, assignments were confirmed by ${ }^{1} \mathrm{H}-{ }^{1} \mathrm{H}$ gCOSY. ${ }^{13} \mathrm{C}$ NMR (125 MHz, DMSO- $\left.d_{6}\right): \delta(\mathrm{ppm})=170.9,170.7,170.5$, 170.3, 170.2, 169.8, $169.4\left(\mathrm{OCOCH}_{3}\right) ; 146.2$ ( $\left.\mathrm{C}_{\text {arom. }}\right) ; 146.0\left(\mathrm{C}_{\text {triazole }}\right) ; 139.6\left(\mathrm{C}_{\text {arom. }}\right)$; 127.9,

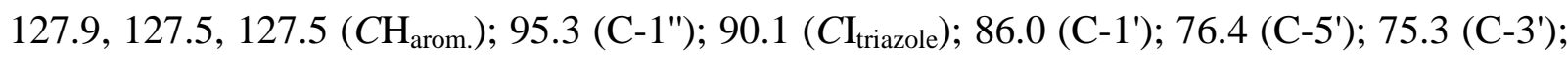
73.7 (C-4'); 70.1 (C-2"); 69.6 (C-3"); 68.8 (C-5"); 68.4 (C-4"); 63.1 (C-2'); 63.0 (C-6'); 61.1 (C6"); $47.8\left(\mathrm{SCH}_{2}\right) ; 24.5,21.4,21.2,21.1,21.0,21.0,21.0\left(\mathrm{OCOCH}_{3}\right)$, assignments were confirmed by ${ }^{1} \mathrm{H}_{-}{ }^{13} \mathrm{C}$ HSQC and ${ }^{1} \mathrm{H}_{-}{ }^{13} \mathrm{C}$ HMBC. LRMS $\left(\mathrm{ESI}^{+}\right): \mathrm{m} / \mathrm{z}=1047[\mathrm{M}+\mathrm{H}]^{+}, 1069[\mathrm{M}$ $+\mathrm{Na}]^{+}$. HRMS: Calcd for $\mathrm{C}_{35} \mathrm{H}_{44} \mathrm{I}_{1} \mathrm{~N}_{4} \mathrm{O}_{21} \mathrm{~S}_{2}$ 1047.0979, Found 1047.0991.

p-(4-\{[2',2",3',3"',4',6',6"'-Hepta-O-acetyl- $\beta$-maltosyl]sulfonylmethyl\}-1-H-1,2,3-triazol-1yl)benzenesulfonamide (16)

The title compound $\mathbf{1 6}$ was prepared from compound $\mathbf{1 0}$ according to the general procedure 3. Purification by flash chromatography (3:1 EtOAc/hexane) afforded the title compound 16 $(57 \%$ yield $)$ as a white foam. m.p. $=114-116{ }^{\circ} \mathrm{C} .[\alpha]^{25} \mathrm{D}=+67(c=1.0$, chloroform $) .{ }^{1} \mathrm{H}$ NMR $\left(500 \mathrm{MHz}, \mathrm{DMSO}-\mathrm{d}_{6}\right): \delta(\mathrm{ppm})=8.88\left(\mathrm{~s}, 1 \mathrm{H}, \mathrm{CH}_{\text {triazole }}\right) ; 8.17,8.05(2 \times \mathrm{d}, J=8.5 \mathrm{~Hz}, 4 \mathrm{H}$, $\mathrm{H}_{\text {arom.); }} 7.52$ (s, 2H, $\mathrm{NH}_{2}$ ); 5.45 (t, $J=9.0 \mathrm{~Hz}, 1 \mathrm{H}, \mathrm{H}-3$ '); 5.30 (d, $J=3.5 \mathrm{~Hz}, 1 \mathrm{H}, \mathrm{H}-1$ "); 5.27 (t, $J=9.5 \mathrm{~Hz}, 1 \mathrm{H}, \mathrm{H}-2$ '); 5.23 (t, $\left.J=10.0 \mathrm{~Hz}, 1 \mathrm{H}, \mathrm{H}-3^{\prime \prime}\right) ; 5.14$ (d, $\left.J=10.0 \mathrm{~Hz}, 1 \mathrm{H}, \mathrm{H}-1^{\prime}\right) ; 5.00$ (t, $J$ $=10.0 \mathrm{~Hz}, 1 \mathrm{H}, \mathrm{H}-4 ") ; 4.89$ (dd, $J=11.0,4.0 \mathrm{~Hz}, 1 \mathrm{H}, \mathrm{H}-2 ") ; 4.79$ (d, $J=15.0 \mathrm{~Hz}, 1 \mathrm{H}, \mathrm{SCH} H$ ); 4.72 (d, $J=15.0 \mathrm{~Hz}, 1 \mathrm{H}, \mathrm{SCHH}) ; 4.55$ (dd, $J=12.0,2.5 \mathrm{~Hz}, 1 \mathrm{H}, \mathrm{H}-6 \mathrm{a}$ ); 4.26 (dd, $J=12.0,5.5$ Hz, 1H, H-6b'); 4.20 (m, 1H, H-5'); 4.17 (m, 1H, H-6a"); 4.05 (m, 1H, H-6b"); 4.03 (m, 1H, H4'); $4.00(\mathrm{~m}, 1 \mathrm{H}, \mathrm{H}-5 ") ; 2.08,2.03,2.02,1.99,1.98,1.95,1.90\left(7 \times \mathrm{s}, 21 \mathrm{H}, \mathrm{COCH}_{3}\right)$, assignments were confirmed by ${ }^{1} \mathrm{H}-{ }^{1} \mathrm{H}$ gCOSY. ${ }^{13} \mathrm{C}$ NMR $\left(125 \mathrm{MHz}\right.$, DMSO- $\left.d_{6}\right): \delta(\mathrm{ppm})=$ 170.2, 170.0, 169.8, 169.6, 169.5, 169.1, $168.7\left(\mathrm{OCOCH}_{3}\right) ; 144.1,138.4\left(\mathrm{C}_{\text {arom. }}\right) ; 135.5$ 
( $\left.\mathrm{C}_{\text {triazole }}\right)$; 127.7, 127.7 ( $\left.\mathrm{CH}_{\text {arom. }}\right)$; 125.9 ( $\left.\mathrm{CH}_{\text {triazole }}\right)$; 120.5, 120.5 ( $\left.\mathrm{CH}_{\text {arom. }}\right)$; 95.6 (C-1"); 84.5 (C1'); 75.5 (C-5'); 74.6 (C-3'); 73.1 (C-4'); 68.9 (C-3"); 68.4 (C-2"); 68.1 (C-5"); 67.8 (C-4"); 66.4 (C-2'); 62.5 (C-6'); 61.5 (C-6"); $47.0\left(\mathrm{SO}_{2} \mathrm{CH}_{2}\right)$; 20.6, 20.5, 20.4, 20.3, 20.3, 20.2, 20.2 $\left(\mathrm{OCOCH}_{3}\right)$, assignments were confirmed by ${ }^{1} \mathrm{H}_{-}{ }^{13} \mathrm{C}$ HSQC and ${ }^{1} \mathrm{H}_{-}-{ }^{13} \mathrm{C}$ HMBC. LRMS $\left(\mathrm{ESI}^{+}\right)$: $m / z=921[\mathrm{M}+\mathrm{H}]^{+}, 943[\mathrm{M}+\mathrm{Na}]^{+}$. HRMS: Calcd for $\mathrm{C}_{35} \mathrm{H}_{44} \mathrm{~N}_{4} \mathrm{O}_{21} \mathrm{~S}_{2} \mathrm{Na}_{1}$ 943.1837, Found 943.1842.

p-(4-\{( $\beta$-D-Glucopyranosyl)thiomethyl\}-5-iodo-1-H-1,2,3-triazol-1-yl)benzenesulfonamide (17)

The title compound $\mathbf{1 7}$ was prepared from compound $\mathbf{5}$ according to the general procedure 4 . Lyophilisation afforded the title compound 17 (92\% yield) as a highly hygroscopic white solid. $[\alpha]^{25}=-64\left(c=1.0\right.$, methanol). ${ }^{1} \mathrm{H}$ NMR $\left(500 \mathrm{MHz}, \mathrm{DMSO}-\mathrm{d}_{6}\right): \delta(\mathrm{ppm})=8.06(2 \times \mathrm{d}, J=$ $8.5 \mathrm{~Hz}, 4 \mathrm{H}, \mathrm{H}_{\text {arom. }}$ ); 7.58 (s, 2H, NH ); 5.15 (d, $\left.J=6.0 \mathrm{~Hz}, 1 \mathrm{H}, \mathrm{OH}\right) ; 5.01$ (br s, $1 \mathrm{H}, \mathrm{OH}$ ); 4.92 (br s, 1H, OH); 4.50 (t, $J=5.5 \mathrm{~Hz}, 1 \mathrm{H}, \mathrm{OH}-6) ; 4.42$ (d, $J=9.5 \mathrm{~Hz}, 1 \mathrm{H}, \mathrm{H}-1$ ); 4.05 (d, $J=14.0$ Hz, 1H, SCHa); 3.91 (d, $J=14.0 \mathrm{~Hz}, 1 \mathrm{H}, \mathrm{SCHb}$ ); 3.70 (dd, $J=11.0,5.5 \mathrm{~Hz}, 1 \mathrm{H}, \mathrm{H}-6 \mathrm{a}$ ); 3.49 (m, 1H, H-6b); 3.18 (m, 3H, H-3, H-4, H-5); 3.06 (m, 1H, H-2), assignments were confirmed by ${ }^{1} \mathrm{H}-{ }^{1} \mathrm{H}$ gCOSY. ${ }^{13} \mathrm{C}$ NMR (500 MHz; DMSO): $\delta$ (ppm) = 150.0 (C arom.); 145.2 (C triazole $)$, 139.0 ( $\left.\mathrm{C}_{\text {arom. }}\right)$; 127.0, 127.0, 126.6, $126.6\left(\mathrm{CH}_{\text {arom. }}\right)$; 84.7 ( $\left.\mathrm{CI}_{\text {triazole }}\right) ; 84.3$ (C-1'); 80.8 (C-5'); 78.2 (C-3'); 73.1 (C-4'); $69.9(\mathrm{C}-2 ') ; 61.1\left(\mathrm{C}-6^{\prime}\right)$; $23.6\left(\mathrm{SCH}_{2}\right)$, assignments were confirmed by ${ }^{1} \mathrm{H}^{-13} \mathrm{C}$ HSQC. LRMS $\left(\mathrm{ESI}^{+}\right): \mathrm{m} / \mathrm{z}=559[\mathrm{M}+\mathrm{H}]^{+}, 576\left[\mathrm{M}+\mathrm{NH}_{4}\right]^{+}, 781[\mathrm{M}+\mathrm{Na}]^{+} . \mathrm{HRMS}:$ Calcd for $\mathrm{C}_{15} \mathrm{H}_{20} \mathrm{IN}_{4} \mathrm{O}_{7} \mathrm{~S}_{2}$ 558.9813, Found 558.9811.

\section{$p$-(4-\{( $\beta$-D-Glucopyranosyl)thiomethyl\}-1-H-1,2,3-triazol-1-yl)benzenesulfonamide (18)}

The title compound $\mathbf{1 8}$ was prepared from compound $\mathbf{6}$ according to the general procedure 4 . Lyophilisation afforded the title compound 18 (97\% yield) as a highly hygroscopic white solid. 
$[\alpha]^{25}=-60\left(c=1.0\right.$, methanol). ${ }^{1} \mathrm{H}$ NMR $\left(500 \mathrm{MHz}, \mathrm{DMSO}-d_{6}\right): \delta(\mathrm{ppm})=8.83(\mathrm{~s}, 1 \mathrm{H}$, $\left.\mathrm{CH}_{\text {triazole }}\right)$; 8.11, $8.02\left(2 \times \mathrm{d}, J=9.0 \mathrm{~Hz}, 4 \mathrm{H}, \mathrm{H}_{\text {arom. }}\right) ; 7.51\left(\mathrm{~s}, 2 \mathrm{H}, \mathrm{NH}_{2}\right) ; 5.16$ (d, $J=6.0 \mathrm{~Hz}, 1 \mathrm{H}$, $\mathrm{OH}) ; 5.02(\mathrm{~d}, J=4.5 \mathrm{~Hz}, 1 \mathrm{H}, \mathrm{OH}) ; 4.95$ (d, $J=5.5 \mathrm{~Hz}, 1 \mathrm{H}, \mathrm{OH}) ; 4.76$ (t, $J=5.5 \mathrm{~Hz}, 1 \mathrm{H}, \mathrm{OH}-$ 6); 4.34 (d, $J=10.0 \mathrm{~Hz}, 1 \mathrm{H}, \mathrm{H}-1$ '); 4.10 (d, $J=14.5 \mathrm{~Hz}, 1 \mathrm{H}, \mathrm{SCHa}) ; 3.95$ (d, $J=14.0 \mathrm{~Hz}, 1 \mathrm{H}$, SCHb); 3.76 (m, 1H, H-6a'); 3.47 (m, 1H, H-6b'); 3.19 (m, 1H, H-5'); 3.14 (m, 1H, H-3'); 3.08 (m, 1H, H-4'); 3.05 (m, 1H, H-2'), assignments were confirmed by ${ }^{1} \mathrm{H}-{ }^{1} \mathrm{H}$ gCOSY.${ }^{13} \mathrm{C}$ NMR (500 MHz; DMSO): $\delta(\mathrm{ppm})=146.2\left(\mathrm{C}_{\text {triazole }}\right) ; 143.6,138.6\left(\mathrm{C}_{\text {arom. }}\right) ; 127.5,127.5\left(\mathrm{CH}_{\text {arom. }}\right)$; 121.8 ( $\left.\mathrm{CH}_{\text {triazole }}\right) ; 120.0,120.0\left(\mathrm{CH}_{\text {arom. }}\right)$; $84.2\left(\mathrm{C}-1^{\prime}\right) ; 81.1$ (C-5'); $78.1\left(\mathrm{C}-3^{\prime}\right) ; 73.1\left(\mathrm{C}-4^{\prime}\right) ; 70.1$ (C-2'); 61.3 (C-6'); $23.0\left(\mathrm{SCH}_{2}\right)$, assignments were confirmed by ${ }^{1} \mathrm{H}^{13}{ }^{13} \mathrm{C}$ HSQC. LRMS $\left(\mathrm{ESI}^{+}\right)$: $m / z=433[\mathrm{M}+\mathrm{H}]^{+}, 450\left[\mathrm{M}+\mathrm{NH}_{4}\right]^{+}, 455[\mathrm{M}+\mathrm{Na}]^{+}$. HRMS: Calcd for $\mathrm{C}_{15} \mathrm{H}_{20} \mathrm{~N}_{4} \mathrm{O}_{7} \mathrm{~S}_{2} \mathrm{Na}$ 455.0665, Found 455.0657. Analytical data is consistent with values reported in the literature. $^{18}$

\section{p-(4-\{(ß-D-Galactopyranosyl)thiomethyl\}-5-iodo-1-H-1,2,3-triazol-1-}

\section{yl)benzenesulfonamide (19)}

The title compound 19 was prepared from compound 7 according to the general procedure 4 . Lyophilisation afforded the title compound 19 (91\% yield) as a highly hygroscopic white solid. $[\alpha]^{25}{ }_{\mathrm{D}}=-57\left(c=1.0\right.$, methanol). ${ }^{1} \mathrm{H}$ NMR $\left(500 \mathrm{MHz}, \mathrm{DMSO}-\mathrm{d}_{6}\right): \delta(\mathrm{ppm})=8.06,7.85(2 \times \mathrm{d}$, $\left.J=8.5 \mathrm{~Hz}, 4 \mathrm{H}, \mathrm{H}_{\text {arom. }}\right) ; 7.58$ (s, 2H, $\mathrm{NH}_{2}$ ); 4.37 (d, $\left.J=9.5 \mathrm{~Hz}, 1 \mathrm{H}, \mathrm{H}-1^{\prime}\right) ; 4.02$ (d, $J=14.0 \mathrm{~Hz}$, 1H, SCHa); 3.91 (d, $J=14.0 \mathrm{~Hz}, 1 \mathrm{H}, \mathrm{SCHb}) ; 3.73$ (d, $J=3.0 \mathrm{~Hz}, 1 \mathrm{H}, \mathrm{H}-4$ '); 3.54-3.50 (m, 2H, H-5', H-6a'); 3.42 (br d, $J=10.5$ Hz, 1H, H-6b'); 3.41 (t, $J=9.5 \mathrm{~Hz}, 1 \mathrm{H}, \mathrm{H}-2$ '); 3.29 (dd, $J=$ 9.5, 3.0 Hz, $\left.1 \mathrm{H}, \mathrm{H}-3^{\prime}\right)$, assignments were confirmed by ${ }^{1} \mathrm{H}-{ }^{1} \mathrm{H}$ gCOSY. ${ }^{13} \mathrm{C}$ NMR (500 MHz; DMSO): $\delta(\mathrm{ppm})=150.0\left(\mathrm{C}_{\text {arom. }}\right) ; 145.3$ ( $\left.\mathrm{C}_{\text {triazole }}\right) ; 139.1\left(\mathrm{C}_{\text {arom. }}\right) ; 127.1,127.1,126.7,126.7$ ( $\left.\mathrm{CH}_{\text {arom. }}\right)$; 85.0 (CI $\left.\mathrm{I}_{\text {triazole }}\right) ; 84.8$ (C-1'); 79.1 (C-5'); 74.8 (C-3'); 70.0 (C-4'); 68.3 (C-2'); 60.4 (C6'); $23.8\left(\mathrm{SCH}_{2}\right)$, assignments were confirmed by ${ }^{1} \mathrm{H}^{-13} \mathrm{C}$ HSQC. LRMS $\left(\mathrm{ESI}^{+}\right): \mathrm{m} / \mathrm{z}=573[\mathrm{M}$ 
$+\mathrm{H}]^{+}, 590\left[\mathrm{M}+\mathrm{NH}_{4}\right]^{+}, 595[\mathrm{M}+\mathrm{Na}]^{+}$. HRMS: Calcd for $\mathrm{C}_{15} \mathrm{H}_{20} \mathrm{IN}_{4} \mathrm{O}_{7} \mathrm{~S}_{2}$ 558.9813, Found 558.9793.

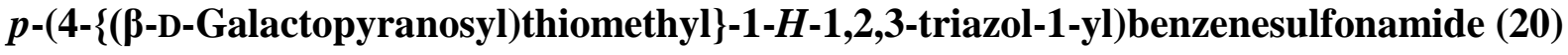
The title compound $\mathbf{2 0}$ was prepared from compound $\mathbf{8}$ according to the general procedure 4 . Lyophilisation afforded the title compound 20 (96\% yield) as a highly hygroscopic white solid. $[\alpha]^{25}=-49\left(c=1.0\right.$, methanol). ${ }^{1} \mathrm{H}$ NMR $\left(500 \mathrm{MHz}, \mathrm{DMSO}-d_{6}\right): \delta(\mathrm{ppm})=8.82(\mathrm{~s}, 1 \mathrm{H}$, $\left.\mathrm{CH}_{\text {triazole }}\right) ; 8.10,8.01\left(2 \times \mathrm{d}, J=9.0 \mathrm{~Hz}, 4 \mathrm{H}, \mathrm{H}_{\text {arom. }}\right) ; 7.50\left(\mathrm{~s}, 2 \mathrm{H}, \mathrm{NH}_{2}\right) ; 5.00$ (d, $J=6.0 \mathrm{~Hz}, 1 \mathrm{H}$, $\mathrm{OH}) ; 4.79(\mathrm{~d}, J=5.5 \mathrm{~Hz}, 1 \mathrm{H}, \mathrm{OH}) ; 4.73(\mathrm{t}, J=5.0 \mathrm{~Hz}, 1 \mathrm{H}, \mathrm{OH}-6) ; 4.47$ (d, $J=4.5 \mathrm{~Hz}, 1 \mathrm{H}$, $\mathrm{OH}) ; 4.28(\mathrm{~d}, J=9.5 \mathrm{~Hz}, 1 \mathrm{H}, \mathrm{H}-1$ '); 4.08 (d, $J=14.0 \mathrm{~Hz}, 1 \mathrm{H}, \mathrm{SCHa}) ; 3.93$ (d, $J=14.0 \mathrm{~Hz}, 1 \mathrm{H}$, $\mathrm{SCHb}$ ); 3.70 (m, 1H, H-4'); 3.55-3.52 (m, 2H, H-6a', H-6b'); 3.44-3.41 (m, 2H, H-2', H-5'); $3.30\left(\mathrm{~m}, 1 \mathrm{H}, \mathrm{H}-3\right.$ '), assignments were confirmed by ${ }^{1} \mathrm{H}-{ }^{1} \mathrm{H}$ gCOSY. ${ }^{13} \mathrm{C}$ NMR $(125 \mathrm{MHz}$, DMSO-d $\left.{ }_{6}\right): \delta(\mathrm{ppm})=146.2\left(\mathrm{C}_{\text {arom }}\right) ; 143.6\left(\mathrm{C}_{\text {triazole }}\right) ; 138.6\left(\mathrm{C}_{\text {arom }}\right) ; 127.5,127.5\left(\mathrm{CH}_{\text {arom. }}\right)$; $121.8\left(\mathrm{CH}_{\text {triazole }}\right) ; 120.0,120.0\left(\mathrm{CH}_{\text {arom. }}\right) ; 84.6$ (C-1'); 79.4 (C-5'); 74.6 (C-3'); 69.8 (C-4'); 68.6 (C-2'); 60.9 (C-6'); $22.9\left(\mathrm{SCH}_{2}\right)$, assignments were confirmed by ${ }^{1} \mathrm{H}^{13}{ }^{13} \mathrm{C}$ HQC. LRMS $\left(\mathrm{ESI}^{+}\right)$: $m / z=433[\mathrm{M}+\mathrm{H}]^{+}, 450\left[\mathrm{M}+\mathrm{NH}_{4}\right]^{+}, 455[\mathrm{M}+\mathrm{Na}]^{+}$. HRMS: Calcd for $\mathrm{C}_{15} \mathrm{H}_{20} \mathrm{~N}_{4} \mathrm{O}_{7} \mathrm{~S}_{2} \mathrm{Na}$ 455.0665, Found 455.0645. Analytical data is consistent with values reported in the literature. $^{18}$

\section{p-(4-\{( $\beta$-D-Glucopyranosyl)sulfonylmethyl\}-5-iodo-1-H-1,2,3-triazol-1-}

\section{yl)benzenesulfonamide (21)}

The title compound $\mathbf{2 1}$ was prepared from compound $\mathbf{1 1}$ according to the general procedure 4 . Lyophilisation afforded the title compound 21 (93\% yield) as a highly hygroscopic white solid. $[\alpha]^{25}=-19\left(c=1.0\right.$, methanol). ${ }^{1} \mathrm{H}$ NMR $\left(500 \mathrm{MHz}, \mathrm{DMSO}-\mathrm{d}_{6}\right): \delta(\mathrm{ppm})=8.08,7.88(2 \times \mathrm{d}$, $J=8.5 \mathrm{~Hz}, 4 \mathrm{H}, \mathrm{H}_{\text {arom. }}$ ); 7.60 (s, 2H, $\mathrm{NH}_{2}$ ); 5.53 (d, $\left.J=6.0 \mathrm{~Hz}, 1 \mathrm{H}, \mathrm{OH}\right) ; 5.22$ (d, $J=5.5 \mathrm{~Hz}$, 
1H, OH); 5.11 (d, $J=5.5 \mathrm{~Hz}, 1 \mathrm{H}, \mathrm{OH}) ; 4.75(\mathrm{t}, J=6.0 \mathrm{~Hz}, 1 \mathrm{H}, \mathrm{OH}) ; 4.76$ (d, $J=14.5 \mathrm{~Hz}, 1 \mathrm{H}$, SCHa); 4.66 (d, $J=14.5$ Hz, 1H, SCHb); 4.56 (d, $J=9.5$ Hz, 1H, H-1'); 3.76 (dd, $J=11.0,7.0$ Hz, 1H, H-6a'); 3.61 (m, 1H, H-2'); 3.52 (m, 1H, H-6b'); 3.38-3.28 (m, 2H, H-3', H-5'); 3.14 (m, $1 \mathrm{H}, \mathrm{H}-4$ '), assignments were confirmed by ${ }^{1} \mathrm{H}-{ }^{1} \mathrm{H}$ gCOSY.${ }^{13} \mathrm{C}$ NMR (500 MHz; DMSO): $\delta$ $\left.(\mathrm{ppm})=145.5\left(\mathrm{C}_{\text {arom }}\right) ; 141.6\left(\mathrm{C}_{\text {arom. }}\right) ; 138.9\left(\mathrm{C}_{\text {triazole }}\right) ; 127.1,126.8 ;\left(\mathrm{CH}_{\text {arom }}\right)\right) ; 89.8\left(\mathrm{CI}_{\text {triazole }}\right)$; 89.2 (C-1'); 81.9 (C-5'); 77.7 (C-3'); 69.3 (C-4'); 69.3 (C-2'); 60.9 (C-6'); 48.8 (SCH $)$, assignments were confirmed by ${ }^{1} \mathrm{H}^{13}{ }^{13} \mathrm{C}$ HSQC. $\mathrm{LRMS}\left(\mathrm{ESI}^{+}\right): \mathrm{m} / \mathrm{z}=608\left[\mathrm{M}+\mathrm{NH}_{4}\right]^{+}, 613[\mathrm{M}+$ $\mathrm{Na}]^{+}$. HRMS: Calcd for $\mathrm{C}_{15} \mathrm{H}_{19} \mathrm{IN}_{4} \mathrm{O}_{9} \mathrm{~S}_{2}$ 612.9530, Found 612.9538 .

\section{$p$-(4-\{( $\beta$-D-Glucopyranosyl)sulfonylmethyl\}-1-H-1,2,3-triazol-1-yl)benzenesulfonamide} (22)

The title compound 22 was prepared from compound $\mathbf{1 2}$ according to the general procedure 4 . Lyophilisation afforded the title compound 22 (93\% yield) as a highly hygroscopic white solid. $[\alpha]^{25}=-14\left(c=1.0\right.$, methanol). ${ }^{1} \mathrm{H}$ NMR $\left(500 \mathrm{MHz}, \mathrm{DMSO}-d_{6}\right): \delta(\mathrm{ppm})=9.05(\mathrm{~s}, 1 \mathrm{H}$, $\left.\mathrm{CH}_{\text {triazole }}\right) ; 8.12,8.03\left(2 \times \mathrm{d}, J=9.0 \mathrm{~Hz}, 4 \mathrm{H}, \mathrm{H}_{\text {arom. }}\right) ; 7.52\left(\mathrm{~s}, 2 \mathrm{H}, \mathrm{NH}_{2}\right) ; 5.48$ (d, $J=6.0 \mathrm{~Hz}, 1 \mathrm{H}$, $\mathrm{OH}) ; 5.20$ (d, $J=5.0 \mathrm{~Hz}, 1 \mathrm{H}, \mathrm{OH}) ; 5.14$ (d, $J=5.0 \mathrm{~Hz}, 1 \mathrm{H}, \mathrm{OH}) ; 5.04$ (t, $J=5.5 \mathrm{~Hz}, 1 \mathrm{H}, \mathrm{OH}$ ); $4.82(\mathrm{~d}, J=14.5 \mathrm{~Hz}, 1 \mathrm{H}, \mathrm{SCHa}) ; 4.67$ (d, $J=15.0 \mathrm{~Hz}, 1 \mathrm{H}, \mathrm{SCHb}) ; 4.49$ (d, $J=9.5 \mathrm{~Hz}, 1 \mathrm{H}, \mathrm{H}-$ 1'); 3.82 (dd, $J=12.0,5.0$ Hz, 1H, H-6a'); 3.60 (m, 1H, H-2'); 3.44 (m, 1H, H-6b'); 3.42 (m, 1H, H-5'); 3.29 (m, 1H, H-3'); 3.07 (m, 1H, H-4'), assignments were confirmed by ${ }^{1} \mathrm{H}-{ }^{1} \mathrm{H}$ gCOSY. ${ }^{13} \mathrm{C}$ NMR (125 MHz, DMSO-d 6 ): $\delta(\mathrm{ppm})=143.9,138.4\left(\mathrm{C}_{\text {arom. }}\right) ; 136.7$ ( $\left.\mathrm{C}_{\text {triazole }}\right)$; 127.5, 127.5 ( $\left.\mathrm{CH}_{\text {arom. }}\right)$; $124.2\left(\mathrm{CH}_{\text {triazole }}\right) ; 120.3,120.3\left(\mathrm{CH}_{\text {arom. }}\right)$; 88.7 (C-1'); 81.7 (C-5'); 77.4 (C-3'); 69.5 (C-4'); 69.1 (C-2'); 61.1 (C-6'); $48.3\left(\mathrm{SCH}_{2}\right)$, assignments were confirmed by ${ }^{1} \mathrm{H}-$ ${ }^{13} \mathrm{C}$ HSQC. LRMS $\left(\mathrm{ESI}^{+}\right): m / z=482\left[\mathrm{M}+\mathrm{NH}_{4}\right]^{+}, 487[\mathrm{M}+\mathrm{Na}]^{+}$. HRMS: Calcd for $\mathrm{C}_{15} \mathrm{H}_{20} \mathrm{~N}_{4} \mathrm{O}_{9} \mathrm{~S}_{2} \mathrm{Na}$ 487.0564, Found 487.0561. Analytical data is consistent with values reported in the literature. ${ }^{18}$ 
p-(4-\{( $\beta$-D-Galactopyranosyl)sulfonylmethyl\}-5-iodo-1-H-1,2,3-triazol-1yl)benzenesulfonamide (23)

The title compound 23 was prepared from compound $\mathbf{1 3}$ according to the general rocedure 4 . Lyophilisation afforded the title compound 23 (86\% yield) as a highly hygroscopic white solid. $[\alpha]^{25}=-10\left(c=1.0\right.$, methanol). ${ }^{1} \mathrm{H}$ NMR $\left(500 \mathrm{MHz}, \mathrm{DMSO}-d_{6}\right): \delta(\mathrm{ppm})=8.08,7.88(2 \times \mathrm{d}$, $\left.J=8.5 \mathrm{~Hz}, 4 \mathrm{H}, \mathrm{H}_{\text {arom. }}\right) ; 7.59$ (s, $\left.1 \mathrm{H}, \mathrm{NH}_{2}\right) ; 5.35$ (d, $\left.J=6.5 \mathrm{~Hz}, 1 \mathrm{H}, \mathrm{OH}\right) ; 5.00$ (d, $J=6.0 \mathrm{~Hz}$, 1H, OH); $4.71(\mathrm{~d}, J=14.5 \mathrm{~Hz}, 1 \mathrm{H}, \mathrm{SCHa}) ; 4.71(\mathrm{~m}, 1 \mathrm{H}, \mathrm{OH}) ; 4.66(\mathrm{~d}, J=4.0 \mathrm{~Hz}, 1 \mathrm{H}, \mathrm{OH})$; 4.62 (d, $J=14.0 \mathrm{~Hz}, 1 \mathrm{H}, \mathrm{SCHb}) ; 4.49$ (d, $\left.J=9.0 \mathrm{~Hz}, 1 \mathrm{H}, \mathrm{H}-1^{\prime}\right) ; 3.95$ (m, 1H, H-2'); 3.75 (m, 1H, H-6a'); 3.63-3.56 (m, 3H, H-3', H-5', H-6b'); 3.46 (m, 1H, H-4'), assignments were confirmed by ${ }^{1} \mathrm{H}-{ }^{1} \mathrm{H}$ gCOSY.${ }^{13} \mathrm{C}$ NMR (125 MHz, DMSO- $\left.d_{6}\right): \delta(\mathrm{ppm})=145.4,141.6\left(\mathrm{C}_{\text {arom. }}\right.$ ); 138.9 ( $\left.\mathrm{C}_{\text {triazole }}\right)$; 127.1, 126.8 ( $\left.\mathrm{CH}_{\text {arom. }}\right)$; 90.5 ( $\left.\mathrm{CI}_{\text {triazole }}\right)$; 89.2 (C-1'); 80.4 (C-5'); 74.2 (C-3'); 68.0 (C-4'); 66.2 (C-2'); 60.4 (C-6'); $48.8\left(\mathrm{SCH}_{2}\right)$, assignments were confirmed by ${ }^{1} \mathrm{H}^{-13} \mathrm{C}$ HSQC. LRMS $\left(\mathrm{ESI}^{+}\right): \mathrm{m} / \mathrm{z}=608\left[\mathrm{M}+\mathrm{NH}_{4}\right]^{+}, 613[\mathrm{M}+\mathrm{Na}]^{+}$. HRMS: Calcd for $\mathrm{C}_{15} \mathrm{H}_{19} \mathrm{IN}_{4} \mathrm{O}_{9} \mathrm{~S}_{2}$ 612.9530, Found 612.9508.

$p$-(4-\{( $\beta$-D-Galactopyranosyl)sulfonylmethyl\}-1-H-1,2,3-triazol-1-yl)benzenesulfonamide (24)

The title compound $\mathbf{2 4}$ was prepared from compound $\mathbf{1 4}$ according to the general procedure 4 . Lyophilisation afforded the title compound $\mathbf{2 4}$ (86\% yield) as a highly hygroscopic white solid. $[\alpha]^{25}=0\left(c=1.0\right.$, methanol). ${ }^{1} \mathrm{H}$ NMR $\left(500 \mathrm{MHz}, \mathrm{DMSO}-d_{6}\right): \delta(\mathrm{ppm})=9.07(\mathrm{~s}, 1 \mathrm{H}$, $\left.\mathrm{CH}_{\text {triazole }}\right) ;$ 8.10, $8.02\left(2 \times \mathrm{d}, J=9.0 \mathrm{~Hz}, 4 \mathrm{H}, \mathrm{H}_{\text {arom. }}\right) ; 7.50$ (s, 2H, $\left.\mathrm{NH}_{2}\right) ; 4.79$ (d, $J=14.5 \mathrm{~Hz}$, 1H, SCHa); 4.63 (d, $J=14.5 \mathrm{~Hz}, 1 \mathrm{H}, \mathrm{SCHb}) ; 4.39$ (d, $J=9.0 \mathrm{~Hz}, 1 \mathrm{H}, \mathrm{H}-1$ '); 3.92 (t, $J=9.5$ Hz, 1H, H-2'); 3.71 (d, $J=2.5$ Hz, 1H, H-4'); 3.68-3.66 (m, 2H, H-5', H-6a'); 3.57 (m, 1H, H$\left.6 b^{\prime}\right)$; 3.44 (dd, $J=9.0,3.0 \mathrm{~Hz}, 1 \mathrm{H}, \mathrm{H}-3$ '), assignments were confirmed by ${ }^{1} \mathrm{H}-{ }^{1} \mathrm{H}$ gCOSY.${ }^{13} \mathrm{C}$ 
NMR (125 MHz, DMSO- $\left.d_{6}\right): \delta(\mathrm{ppm})=144.2,138.3$ ( $\left.\mathrm{C}_{\text {arom. }}\right) ; 136.8\left(\mathrm{C}_{\text {triazole }}\right) ; 127.5,127.5$ ( $\left.\mathrm{CH}_{\text {arom. }}\right)$; 124.3 ( $\left.\mathrm{CH}_{\text {triazole }}\right) ; 120.3,120.3$ ( $\left.\mathrm{CH}_{\text {arom. }}\right) ; 89.5$ (C-1'); 80.5 (C-5'); 73.9 (C-3'); 68.3 (C-4'); 66.0 (C-2'); $61.0\left(\mathrm{C}-6^{\prime}\right) ; 48.3\left(\mathrm{SCH}_{2}\right)$, assignments were confirmed by ${ }^{1} \mathrm{H}^{13}{ }^{13} \mathrm{HSQC}$. LRMS $\left(\mathrm{ESI}^{+}\right): m / z=482\left[\mathrm{M}+\mathrm{NH}_{4}\right]^{+}, 487[\mathrm{M}+\mathrm{Na}]^{+}$. HRMS: Calcd for $\mathrm{C}_{15} \mathrm{H}_{20} \mathrm{~N}_{4} \mathrm{O}_{9} \mathrm{~S}_{2} \mathrm{Na}$ 487.0564, Found 487.0566. Analytical data is consistent with values reported in the literature. ${ }^{18}$

\section{p-(4-\{[ß-Maltosyl]sulfonylmethyl\}-5-iodo-1-H-1,2,3-triazol-1-yl)benzenesulfonamide (25)}

The title compound $\mathbf{2 5}$ was prepared from compound $\mathbf{1 5}$ according to the general procedure 4 . Lyophilisation afforded the title compound 25 (72\% yield) as a highly hygroscopic white solid. $[\alpha]^{25}=+20\left(c=1.0\right.$, methanol). ${ }^{1} \mathrm{H}$ NMR $\left(500 \mathrm{MHz}, \mathrm{DMSO}-d_{6}\right): \delta(\mathrm{ppm})=8.08,7.88(2 \times \mathrm{d}$, $\left.J=9.0 \mathrm{~Hz}, 4 \mathrm{H}, \mathrm{H}_{\text {arom. }}\right) ; 7.59$ (s, 2H, $\left.\mathrm{NH}_{2}\right) ; 5.75,5.69,5.44(3 \times$ br s, $3 \mathrm{H}, \mathrm{OH}) ; 5.08(\mathrm{~d}, J=4.0$ Hz, 1H, H-1"); 4.90 (m, 2H, OH); 4.90 (m, 2H, OH, SCHa); 4.67 (d, J = 14.5 Hz, 1H, SCHb); 4.60 (d, $J=9.5 \mathrm{~Hz}, 1 \mathrm{H}, \mathrm{H}-1$ '); 4.53 (br t, $J=5.5 \mathrm{~Hz}, 1 \mathrm{H}, \mathrm{OH}$ ); 3.82 (m, 1H, H-6a'); 3.69 (m, 4H, H-2', H-4', H-6a", H-6b"); 3.46 (m, 6H, H-2", H-3', H-3", H-5', H-5", H-6b'); 3.07 (m, 1H, H-4"), assignments were confirmed by ${ }^{1} \mathrm{H}-{ }^{1} \mathrm{H}$ gCOSY. ${ }^{13} \mathrm{C}$ NMR (125 MHz, DMSO- $\left.d_{6}\right): \delta$ $(\mathrm{ppm})=145.6\left(\mathrm{C}_{\text {arom. }}\right) ; 141.4\left(\mathrm{C}_{\text {triazole }}\right) ; 138.8\left(\mathrm{C}_{\text {arom. }}\right) ; 127.0,127.0,126.7,126.7\left(\mathrm{CH}_{\text {arom. }}\right)$;

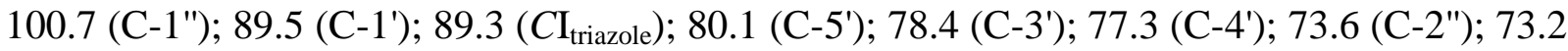
(C-3"); 72.4 (C-5"); 69.9 (C-4"); 69.1 (C-2'); 60.8 (C-6'); 60.4 (C-6"); 48.8 (SCH $)$, assignments were confirmed by ${ }^{1} \mathrm{H}_{-}{ }^{13} \mathrm{C}$ HSQC and ${ }^{1} \mathrm{H}^{13}{ }^{13} \mathrm{CHMC}$. LRMS $\left(\mathrm{ESI}^{+}\right): \mathrm{m} / \mathrm{z}=775$ $[\mathrm{M}+\mathrm{Na}]^{+}$

\section{p-(4-\{[ß-Maltosyl]sulfonylmethyl\}-1-H-1,2,3-triazol-1-yl)benzenesulfonamide (26)}

The title compound $\mathbf{2 6}$ was prepared from compound $\mathbf{1 6}$ according to the general procedure 4 . Lyophilisation afforded the title compound 26 (76\% yield) as a highly hygroscopic white solid. 
$[\alpha]^{25}{ }_{\mathrm{D}}=+11\left(c=1.0\right.$, methanol). ${ }^{1} \mathrm{H}$ NMR $\left(500 \mathrm{MHz}, \mathrm{DMSO}-d_{6}\right): \delta(\mathrm{ppm})=9.02(\mathrm{~s}, 1 \mathrm{H}$, $\left.\mathrm{CH}_{\text {triazole }}\right)$; 8.12, $8.03\left(2 \times \mathrm{d}, J=9.5 \mathrm{~Hz}, 4 \mathrm{H}, \mathrm{H}_{\text {arom. }}\right) ; 7.52$ (br s, $\left.2 \mathrm{H}, \mathrm{NH}_{2}\right) ; 5.70$ (d, $J=3.5 \mathrm{~Hz}$, 1H, OH); $5.62(\mathrm{~d}, J=6.5 \mathrm{~Hz}, 1 \mathrm{H}, \mathrm{OH}) ; 5.46(\mathrm{~d}, J=6.0 \mathrm{~Hz}, 1 \mathrm{H}, \mathrm{OH}) ; 5.06$ (d, $J=4.0 \mathrm{~Hz}, 1 \mathrm{H}$, H-1"); 5.01 (br t, $J=6.0 \mathrm{~Hz}, 1 \mathrm{H}, \mathrm{OH}) ; 4.91$ (d, $J=5.5 \mathrm{~Hz}, 1 \mathrm{H}, \mathrm{OH}) ; 4.87$ (d, $J=5.0 \mathrm{~Hz}, 1 \mathrm{H}$, $\mathrm{OH}) ; 4.84$ (d, $J=15.0 \mathrm{~Hz}, 1 \mathrm{H}, \mathrm{SCHa}) ; 4.68$ (d, $J=14.5 \mathrm{~Hz}, 1 \mathrm{H}, \mathrm{SCHb}) ; 4.56$ (d, $J=9.0 \mathrm{~Hz}$, 1H, H-1'); 4.53 (br t, $J=5.5$ Hz, 1H, OH); 3.87 (m, 1H, H-6a'); 3.63 (m, 5H, H-2', H-4', H-5', H-6a', H-6a", H-6b'); 3.46 (m, 2H, H-2", H-6b"); 3.37 (m, 2H, H-3', H-3"); 3.26 (m, 1H, H-5"); 3.07(m, 1H, H-4"), assignments were confirmed by ${ }^{1} \mathrm{H}^{-1} \mathrm{H}$ gCOSY. ${ }^{13} \mathrm{C}$ NMR $(125 \mathrm{MHz}$, DMSO-d $\left.{ }_{6}\right): \delta(\mathrm{ppm})=144.0,138.4\left(\mathrm{C}_{\text {arom. }}\right) ; 136.6\left(\mathrm{C}_{\text {triazole }}\right) ; 127.5,127.5\left(\mathrm{CH}_{\text {arom. }}\right) ; 124.2$ $\left(\mathrm{CH}_{\text {triazole }}\right) ; 120.4,120.4\left(\mathrm{CH}_{\text {arom. }}\right) ; 100.7$ (C-1"); 88.3 (C-1'); 79.8 (C-5'); 78.7 (C-3'); 77.1 (C4'); 73.6 (C-2"); 73.2 (C-3"); 72.3 (C-5"); 69.9 (C-4"); 68.8 (C-2'); 60.8 (C-6'); 60.7 (C-6"); $48.3\left(\mathrm{SCH}_{2}\right)$, assignments were confirmed by ${ }^{1} \mathrm{H}_{-}{ }^{13} \mathrm{C}$ HSQC and ${ }^{1} \mathrm{H}^{13} \mathrm{C}^{\mathrm{HMBC}}$. LRMS $\left(\mathrm{ESI}^{+}\right)$: $m / z=649[\mathrm{M}+\mathrm{Na}]^{+}$.

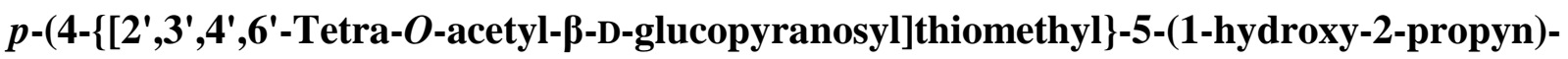

\section{1-H-1,2,3-triazol-1-yl)benzenesulfonamide (27)}

The title compound $\mathbf{2 7}$ was prepared from compound $\mathbf{5}$ according to the general procedure 5 . Purification by flash chromatography (3:1 EtOAc/hexane) afforded the title compound 27 (56\% yield) as a white solid. ${ }^{1} \mathrm{H}$ NMR (500 MHz, DMSO- $\left.d_{6}\right): \delta(\mathrm{ppm})=8.05,8.01(2 \times \mathrm{d}, J=$ $8.5 \mathrm{~Hz}, 4 \mathrm{H}, \mathrm{H}_{\text {arom.); }} 7.57$ (s, 2H, NH$H_{2}$ ); 5.53 (t, $J=6.0 \mathrm{~Hz}, 1 \mathrm{H}, \mathrm{CH}_{2} \mathrm{OH}$ ); 5.31 (t, $J=9.0 \mathrm{~Hz}$, 1H, H-3'); 4.99 (d, $\left.J=10.0 \mathrm{~Hz}, 1 \mathrm{H}, \mathrm{H}-1^{\prime}\right) ; 4.94$ (t, $\left.J=10.0 \mathrm{~Hz}, 1 \mathrm{H}, \mathrm{H}-2^{\prime}\right) ; 4.93$ (t, $J=10.0 \mathrm{~Hz}$, 1H, H-4'); 4.40 (d, $J=6.0 \mathrm{~Hz}, 2 \mathrm{H}, \mathrm{CH}_{2} \mathrm{OH}$ ); 4.13 (dd, $\left.J=13.0,5.0 \mathrm{~Hz}, 1 \mathrm{H}, \mathrm{H}-6 \mathrm{a}^{\prime}\right) ; 4.10$ (d, $J=$ $14.5 \mathrm{~Hz}, 1 \mathrm{H}, \mathrm{SCHa}$ ); 4.02 (d, $J=14.5 \mathrm{~Hz}, 1 \mathrm{H}, \mathrm{SCHb}$ ); 3.99 (m, 2H, H-5, H-6b'); 1.99, 1.98, 1.96, $1.95\left(4 \times \mathrm{s}, 12 \mathrm{H}, \mathrm{OCOCH}_{3}\right)$, assignments were confirmed by ${ }^{1} \mathrm{H}-{ }^{1} \mathrm{H}$ gCOSY.${ }^{13} \mathrm{C}$ NMR (500 MHz; DMSO): $\delta(\mathrm{ppm})=170.0,169.5,169.3,169.2\left(\mathrm{OCOCH}_{3}\right) ; 147.9\left(\mathrm{C}_{\text {arom. }}\right) ; 144.8$ 
$\left(C_{\text {triazole }} \mathrm{CH}_{2}\right) ; 138.0$ ( $\left.\mathrm{C}_{\text {arom. }}\right) ; 127.2,127.2,123.8,123.8\left(\mathrm{CH}_{\text {arom }}\right)$; $118.7,104.0(C \equiv C)$; $81.4(\mathrm{C}-$ 1'); 74.5 (C-5'); 73.0 (C-3'); 69.6 (C-4'); 68.5 (C-2'); $68.0\left(C_{\text {triazole }} \mathrm{C} \equiv \mathrm{C}\right) ; 61.7$ (C-6'); 49.6 $\left(\mathrm{CH}_{2} \mathrm{OH}\right) ; 22.8\left(\mathrm{SCH}_{2}\right) ; 20.4,20.4,20.4,20.3\left(\mathrm{OCOCH}_{3}\right)$, assignments were confirmed by ${ }^{1} \mathrm{H}-$ ${ }^{13} \mathrm{C}$ HSQC. LRMS $\left(\mathrm{ESI}^{+}\right): m / z=655[\mathrm{M}+\mathrm{H}]^{+}, 677[\mathrm{M}+\mathrm{Na}]^{+}$. HRMS: Calcd for $\mathrm{C}_{26} \mathrm{H}_{30} \mathrm{~N}_{4} \mathrm{O}_{12} \mathrm{~S}_{2} \mathrm{Na}$ 677.1194, Found 677.1162.

\section{$p$-(4-\{[2',3',4',6'-Tetra-O-acetyl- $\beta$-D-galactopyranosyl]thiomethyl\}-5-(1-hydroxy-2-}

\section{propyn)-1-H-1,2,3-triazol-1-yl)benzenesulfonamide (28)}

The title compound $\mathbf{2 8}$ was prepared from compound $\mathbf{7}$ according to the general procedure 5 . Purification by flash chromatography (3:1 EtOAc/hexane) afforded the title compound 28 (49\% yield) as a white solid. ${ }^{1} \mathrm{H}$ NMR (500 MHz, DMSO- $\left.d_{6}\right): \delta(\mathrm{ppm})=8.03,8.01(2 \times \mathrm{d}, J=$ $8.5 \mathrm{~Hz}, 4 \mathrm{H}, \mathrm{H}_{\text {arom.); }} 7.57$ (s, 2H, $\mathrm{NH}_{2}$ ); 5.56 (t, $\left.J=6.0 \mathrm{~Hz}, 1 \mathrm{H}, \mathrm{CH}_{2} \mathrm{OH}\right) ; 5.30$ (t, $J=3.5 \mathrm{~Hz}$, 1H, H-4'); 5.21 (dd, $J=10.0,3.5 \mathrm{~Hz}, 1 \mathrm{H}, \mathrm{H}-3$ '); 5.01 (t, $\left.J=10.0 \mathrm{~Hz}, 1 \mathrm{H}, \mathrm{H}-2^{\prime}\right) ; 4.94$ (d, $J=$ $\left.10.0 \mathrm{~Hz}, 1 \mathrm{H}, \mathrm{H}-1^{\prime}\right) ; 4.39$ (d, $J=6.0 \mathrm{~Hz}, 2 \mathrm{H}, \mathrm{CH}_{2} \mathrm{OH}$ ); 4.20 (m, 1H, H-5'); 4.09 (d, $J=14.0 \mathrm{~Hz}$, 1H, SCHa); 4.03 (d, $J=14.0$ Hz, 1H, SCHb); 3.99 (m, 2H, H-6a', H-6b'); 2.10, 1.99, 1.97, 1.91 (4 × s, $\left.12 \mathrm{H}, \mathrm{OCOCH}_{3}\right)$, assignments were confirmed by ${ }^{1} \mathrm{H}-{ }^{1} \mathrm{H}$ gCOSY.${ }^{13} \mathrm{C}$ NMR $(500 \mathrm{MHz}$; DMSO): $\delta(\mathrm{ppm})=170.1,170.0,169.5,169.5\left(\mathrm{OCOCH}_{3}\right) ; 147.9\left(\mathrm{C}_{\text {arom. }}\right) ; 144.8\left(C_{\text {triazole }} \mathrm{CH}_{2}\right)$; 138.0 ( $\left.\mathrm{C}_{\text {arom. }}\right)$; 131.6, 131.5 128.9, $128.8\left(\mathrm{CH}_{\text {arom. }}\right)$; 118.7, $104.1(\mathrm{C} \equiv C)$; $82.4(\mathrm{C}-1)$; 73.6 (C5'); 71.0 (C-3'); $68.4\left(\mathrm{C}-4^{\prime}\right) ; 68.5$ (C-2'); $68.3\left(C_{\text {triazole }} \mathrm{C} \equiv \mathrm{C}\right) ; 61.2\left(\mathrm{C}^{\prime} 6^{\prime}\right) ; 49.6\left(\mathrm{CH}_{2} \mathrm{OH}\right) ; 23.4$ $\left(\mathrm{SCH}_{2}\right)$; 20.5, 20.5, 20.4, $20.4\left(\mathrm{OCOCH}_{3}\right)$, assignments were confirmed by ${ }^{1} \mathrm{H}_{-}{ }^{13} \mathrm{C}$ HSQC. LRMS $\left(\mathrm{ESI}^{+}\right): \mathrm{m} / \mathrm{z}=655[\mathrm{M}+\mathrm{H}]^{+}, 677[\mathrm{M}+\mathrm{Na}]^{+}$. HRMS: Calcd for $\mathrm{C}_{26} \mathrm{H}_{31} \mathrm{~N}_{4} \mathrm{O}_{12} \mathrm{~S}_{2}$ 655.1374, Found 655.1351.

Carbonic anhydrase catalytic inhibition assay. An SX.18MV-R Applied Photophysics stopped-flow instrument has been used for assaying the CA I, II, IX and XII $\mathrm{CO}_{2}$ hydration 
activity. ${ }^{29}$ Phenol red (at a concentration of $0.2 \mathrm{mM}$ ) has been used as indicator, working at the absorbance maximum of $557 \mathrm{~nm}$, with $10 \mathrm{mM}$ Hepes (pH 7.5) as buffer, $0.1 \mathrm{M} \mathrm{NaClO}_{4}$ (for maintaining constant the ionic strength - this anion is not inhibitory), following the CAcatalyzed $\mathrm{CO}_{2}$ hydration reaction for a period of $10-100$ s. Saturated $\mathrm{CO}_{2}$ solutions in water at $20{ }^{\circ} \mathrm{C}$ were used as substrate. Stock solutions of inhibitors were prepared at a concentration of $10-50 \mathrm{mM}$ (in the assay buffer) and dilutions up to $1 \mathrm{nM}$ done with the assay buffer mentioned above. Inhibitor and enzyme solutions were preincubated together for $15 \mathrm{~min}$ at room temperature prior to assay, in order to allow for the formation of the E-I complex. The inhibition constants were obtained by non-linear least-squares methods using PRISM 3. The curve-fitting algorithm allowed us to obtain the $\mathrm{IC}_{50}$ values, working at the lowest concentration of substrate of $1.7 \mathrm{mM}$ ), from which $K_{\mathrm{i}}$ values were calculated by using the Cheng-Prusoff equation. The catalytic activity (in the absence of inhibitors) of these enzymes was calculated from Lineweaver-Burk plots and represent the mean from at least three different determinations. Enzyme concentrations were $10.3 \mathrm{nM}$ for CA I and CA II, $12 \mathrm{nM}$ for CA IX and $15 \mathrm{nM}$ for hCA XII. Enzymes used here were recombinant ones.

\section{Cell Culture and Hypoxic Exposure.}

Chinese hamster lung CCL39 fibroblasts (American Type Culture Collection) and the CCL39derived mutant PS120 cells, lacking the amiloride-sensitive $\mathrm{Na}^{+} / \mathrm{H}^{+}$exchanger, ${ }^{31}$ were maintained in DMEM (Sigma) supplemented with 7.5\% FCS in a humidified atmosphere of $5 \% \mathrm{CO}_{2}, 95 \%$ air, or $100 \%$ air at $37{ }^{\circ} \mathrm{C}$. The colon adenocarcinoma cell lines LS174Tr, expressing the tetracycline (Tet) repressor were maintained in DMEM supplemented with 10\% FCS and blasticidin $\left(10 \mu \mathrm{g} / \mathrm{ml}\right.$, Invitrogen). The incubation in hypoxia at $1 \% \mathrm{O}_{2}$ was carried out at $37{ }^{\circ} \mathrm{C}$ in $95 \%$ humidity and $5 \% \mathrm{CO}_{2} / 94 \% \mathrm{~N}_{2}$ in a sealed anaerobic workstation (Ruskinn). 


\section{Stable Transgenic Cells.}

PS120 cells were transfected with the pca9 vector as previously described. ${ }^{4}$ LS174Tr cells were transfected with Tet $(10 \mu \mathrm{g} / \mathrm{ml})$-inducible short hairpin RNA targeting ca9 (shca9) and transduced with lentiviral particles containing nontarget shRNA (ctl) and shRNA-ca12 (ca12) to constitutively silence ca12, as previously described. ${ }^{4}$ These cells are named, respectively, LS-shca9/ctl and LS-shca9/ca12 cells.

\section{Immunoblotting.}

Cells were lysed in a SDS sample buffer. Proteins $(40 \mu \mathrm{g})$ were separated on $7.5 \%$ SDS polyacrylamide gels and transferred onto polyvinylidene difluoride membranes (Millipore). Membranes were blotted with the monoclonal M75 antibody to CA IX (Bayer), a polyclonal antibody to recombinant CA XII (Sigma), a polyclonal antibody HIF-1 $\alpha$ prepared and validated in our laboratory and Hsp90 (Abcam). Immunoreactive bands were detected with a horseradish peroxidase (HRP) anti-mouse or anti-rabbit antibody (Promega) by enhanced chemiluminescence (Amersham Biosciences).

\section{In cellulo determination of CA activity.}

Exponentially growing cells were scraped into ice-cold PBS to obtain intact cells expressing membrane-bound CAs. The cell suspension was centrifuged and resuspended in a $\mathrm{HCO}_{3}{ }^{-}$-free media (Sigma) buffered at $\mathrm{pH}_{\mathrm{o}}$ of 7.5 with $30 \mathrm{mM}$ HEPES in the presence or absence of the AZA or compound 5 at $60 \mu \mathrm{M}$ for $30 \mathrm{~min}$. A 0.1 volume of this cell suspension was added to a $3 \mathrm{mM}$ HEPES-buffered solution (HBS) adjusted to $\mathrm{pH}_{0} 8.2$ before rapid addition to a $\mathrm{CO}_{2}$ saturated non-buffered solution and the extracellular $\mathrm{pH}$ determined over time (microelectrode, 
Schott Instrument) to monitor the rapid hydration of $\mathrm{CO}_{2}$ to carbonic acid in response to the membrane-associated CAs activity.

\section{Resting $\mathrm{pH}_{\mathrm{i}}$ measurement $\left[{ }^{14} \mathrm{C}\right]$-Benzoic Acid.}

The $\mathrm{pH}_{\mathrm{i}}$ was measured using the technique of distribution of the weak acid $\left[7-{ }^{14} \mathrm{C}\right]$-benzoic acid (Amersham Biosciences) in intracellular and extracellular spaces for exponentially growing cells. ${ }^{4} 1 \mathrm{~h}$ pre-incubation in the absence (DMSO) or in the presence of $60 \mu \mathrm{M}$ of AZA or compound 5 was used before addition of the radioactive ligand.

\section{Cell-based screening of CA IX inhibitors.}

Fibroblasts expressing CA IX (PS120-pca9 cells) and control fibroblasts (PS120-pev cells) were seeded onto 12 well plates. Once attached, the medium was replaced by $\mathrm{HCO}_{3}{ }^{-}$-free DMEM buffered at either $\mathrm{pH}_{0} 6.4$ (30 mM MES) or $\mathrm{pH}_{0} 7.5$ (30 mM HEPES), supplemented with $10 \%$ dialyzed serum, hypoxanthine $0.1 \mathrm{mM}$ and uridine triphosphate $0.1 \mathrm{mM}$ for $24 \mathrm{~h}$ of growth in a $\mathrm{CO}_{2} / \mathrm{HCO}_{3}{ }^{-}$-free atmosphere without (DMSO) or with $60 \mu \mathrm{M}$ of the CA inhibitors. Plates were then returned to $5 \% \mathrm{CO}_{2}$ in a regular media for 7 days before staining with Giemsa (Fluka).

\section{Proliferation assay.}

Tetracycline $(1 \mu \mathrm{g} / \mathrm{ml})$ was added in the medium of LS-shca9/ca12- cells 4 days before the assay. LS-shca9/ctl -Tet and LS-shca9/ca12 ${ }^{-}$+Tet cells $\left(6 \times 10^{4}\right)$ were seeded onto 6 well plates in the absence or presence of Tet. $24 \mathrm{~h}$ after seeding, cells were incubated in hypoxia (1 $\% \mathrm{O}_{2}$ ) in the presence or in the absence of CA inhibitors. Every 24 h during 3 days cells were detached and counted with Coulter Z1 (Beckman). The proliferation index was calculated by 
dividing the total cell number obtained each day by the cell number obtained $24 \mathrm{~h}$ after seeding.

Supporting Information Available: ${ }^{1} \mathrm{H}$ NMR spectra of compounds 5-28. This material is available free of charge via the Internet at http://pubs.acs.org.

\section{Acknowledgements.}

This research was financed in part by the Australian Research Council (Grant number DP110100071) and by a grant of the $7^{\text {th }}$ FP of EU (Metoxia project).

\section{References}

1. Brahimi-Horn, M. C.; Bellot, G.; Pouysségur, J., Hypoxia and energetic tumour metabolism. Curr. Opin. Gen. Dev. 2011, 21, 67-72.

2. Brahimi-Horn, M. C.; Pouyssegur, J., HIF at a glance. J. Cell Sci. 2009, 122 (8), 10551057.

3. Swietach, P.; Vaughan-Jones, R.; Harris, A., Regulation of tumor $\mathrm{pH}$ and the role of carbonic anhydrase 9. Cancer Metastasis Rev. 2007, 26 (2), 299-310.

4. Chiche, J.; Ilc, K.; Laferriere, J.; Trottier, E.; Dayan, F.; Mazure, N. M.; Brahimi-Horn, M. C.; Pouyssegur, J., Hypoxia-Inducible Carbonic Anhydrase IX and XII Promote Tumor Cell Growth by Counteracting Acidosis through the Regulation of the Intracellular pH. Cancer Res. 2009, 69 (1), 358-368.

5. Supuran, C. T., Carbonic anhydrases: novel therapeutic applications for inhibitors and activators. Nat. Rev. Drug Discov. 2008, 7 (2), 168-181.

6. Svastova, E.; Hulikova, A.; Rafajova, M.; Zatovicova, M.; Gibadulinova, A.; Casini, A.; Cecchi, A.; Scozzafava, A.; Supuran, C. T.; Pastorek, J.; Pastoreková, S., Hypoxia activates 
the capacity of tumor-associated carbonic anhydrase IX to acidify extracellular pH. FEBS Letters 2004, 577, 439-445.

7. (a) Potter, C. P. S.; Harris, A. L., Diagnostic, prognostic and therapeutic implications of carbonic anhydrases in cancer. Br. J. Cancer 2003, 89 (1), 2-7; (b) Wykoff, C. C.; Beasley, N. J.; Watson, P. H.; Turner, K. J.; Pastorek, J.; Sibtain, A.; Wilson, G. D.; Turley, H.; Talks, K. L.; Maxwell, P. H.; Pugh, C. W.; Ratcliffe, P. J.; Harris, A. L., Hypoxia-inducible Expression of Tumor-associated Carbonic Anhydrases. Cancer Res. 2000, 60 (24), 7075-7083.

8. $\quad$ Bleumer, I.; Knuth, A.; Oosterwijk, E.; Hofmann, R.; Varga, Z.; Lamers, C.; Kruit, W.; Melchior, S.; Mala, C.; Ullrich, S.; De Mulder, P.; Mulders, P. F. A.; Beck, J., A phase II trial of chimeric monoclonal antibody G250 for advanced renal cell carcinoma patients. Br. $J$. Cancer 2004, 90, 985-990.

9. (a) Ahlskog, J. K.; Dumelin, C. E.; Trussel, S.; Marlind, J.; Neri, D. I., In vivo targeting of tumor-associated carbonic anhydrases using acetazolamide derivatives. Bioorg. Med. Chem. Lett. 2009, 19, 4851-4856; (b) Lou, Y.; McDonald, P. C.; Oloumi, A.; Chia, S.; Ostlund, C.; Ahmadi, A.; Kyle, A.; auf dem Keller, U.; Leung, S.; Huntsman, D.; Clarke, B.; Sutherland, B. W.; Waterhouse, D.; Bally, M.; Roskelley, C.; Overall, C. M.; Minchinton, A.; Pacchiano, F.; Carta, F.; Scozzafava, A.; Touisni, N.; Winum, J.-Y.; Supuran, C. T.; Dedhar, S., Targeting Tumor Hypoxia: Suppression of Breast Tumor Growth and Metastasis by Novel Carbonic Anhydrase IX Inhibitors. Cancer Res. 2011, 71, 3364-3376.

10. Pastorekova, S.; Casini, A.; Scozzafava, A.; Vullo, D.; Pastorek, J.; Supuran, C. T. Carbonic anhydrase inhibitors: The first selective, membrane-impermeant inhibitors targeting the tumor-associated isozyme IX. Bioorg. Med. Chem. Lett. 2004, 14, 869-873.

11. Scozzafava, A.; Briganti, F.; Ilies, M. A.; Supuran, C. T. Carbonic anhydrase inhibitors: Synthesis of membrane-impermeant low molecular weight sulfonamides possessing in vivo 
selectivity for the membrane-bound versus cytosolic isozymes. J. Med. Chem. 2000, 43, 292300.

12. Loughrey, B. T.; Williams, M. L.; Healy, P. C.; Innocenti, A.; Vullo, D.; Supuran, C. T.; Parsons, P. G.; Poulsen, S. A. Novel organometallic cationic ruthenium(II) pentamethylcyclopentadienyl benzenesulfonamide complexes targeted to inhibit carbonic anhydrase. J. Biol. Inorg. Chem. 2009, 14, 935-945.

13. (a) Wilkinson, B. L.; Bornaghi, L. F.; Poulsen, S. A.; Houston, T. A., Synthetic utility of glycosyl triazoles in carbohydrate chemistry. Tetrahedron 2006, 62 (34), 8115-8125; (b) Wilkinson, B. L.; Bornaghi, L. F.; Houston, T. A.; Innocente, A.; Supuran, C. T.; Poulsen, S.A., A novel class of carbonic anhydrase inhibitors: Glycoconjugate benzene sulfonamides prepared by "click-tailing". J. Med. Chem. 2006, 49 (22), 6539-6548.

14. (a) Wilkinson, B. L.; Bornaghi, L. F.; Houston, T. A.; Innocenti, A.; Vullo, D.; Supuran, C. T.; Poulsen, S.-A., Carbonic Anhydrase Inhibitors: Inhibition of Isozymes I, II, and IX with Triazole-Linked O-Glycosides of Benzene Sulfonamides. J. Med. Chem. 2007, 50 (7), 1651-1657; (b) Wilkinson, B. L.; Bornaghi, L. F.; Houston, T. A.; Innocenti, A.; Vullo, D.; Supuran, C. T.; Poulsen, S.-A., Inhibition of membrane-associated carbonic anhydrase isozymes IX, XII and XIV with a library of glycoconjugate benzenesulfonamides. Bioorg. Med. Chem. Lett. 2007, 17 (4), 987-992.

15. Wilkinson, B. L.; Innocenti, A.; Vullo, D.; Supuran, C. T.; Poulsen, S.-A., Inhibition of Carbonic Anhydrases with Glycosyltriazole Benzene Sulfonamides. J. Med. Chem. 2008, 51 (6), 1945-1953.

16. (a) Winum, J.-Y.; Poulsen, S.-A.; Supuran, C. T., Therapeutic applications of glycosidic carbonic anhydrase inhibitors. Med. Res. Rev. 2009, 29 (3), 419-435; (b) Lopez, M.; Bornaghi, L. F.; Innocenti, A.; Vullo, D.; Charman, S. A.; Supuran, C. T.; Poulsen, S.-A., Sulfonamide Linked Neoglycoconjugates - A New Class of Inhibitors for Cancer-Associated 
Carbonic Anhydrases. J. Med. Chem. 2010, 53 (7), 2913-2926; (c) Lopez, M.; Paul, B.; Hofmann, A.; Morizzi, J.; Wu, Q. K.; Charman, S. A.; Innocenti, A.; Vullo, D.; Supuran, C. T.; Poulsen, S.-A., S-Glycosyl Primary Sulfonamides - A New Structural Class for Selective Inhibition of Cancer-Associated Carbonic Anhydrases. J. Med. Chem. 2009, 52 (20), 64216432.

17. Chiche, J.; Brahimi-Horn, M.; Pouysségur, J., Tumour hypoxia induces a metabolic shift causing acidosis: a common feature in cancer. J Cell Mol. Med. 2010, 14 (4), 771-794.

18. Singer, M.; Lopez, M.; Bornaghi, L. F.; Innocenti, A.; Vullo, D.; Supuran, C. T.; Poulsen, S.-A., Inhibition of carbonic anhydrase isozymes with benzene sulfonamides incorporating thio, sulfinyl and sulfonyl glycoside moieties. Bioorg. Med. Chem. Lett. 2009, 19 (8), 2273-2276.

19. (a) Meutermans, W.; Le, G. T.; Becker, B., Carbohydrates as scaffolds in drug discovery. ChemMedChem 2006, 1, 1164-1194; (b) Elmouelhi, N.; Aich, U.; Paruchuri, V. D.; Meledeo, M. A.; Campbell, C. T.; Wang, J. J.; Srinivas, R.; Khanna, H. S.; Yarema, K. J., Hexosamine Template. A Platform for Modulating Gene Expression and for Sugar-Based Drug Discovery. J. Med. Chem. 2009, 52 (8), 2515-2530; (c) Aich, U.; Campbell, C. T.; Elmouelhi, N.; Weier, C. A.; Sampathkumar, S.-G.; Choi, S. S.; Yarema, K. J., Regioisomeric SCFA Attachment to Hexosamines Separates Metabolic Flux from Cytotoxicity and MUC1 Suppression. ACS Chem. Biol. 2008, 3 (4), 230-240; (d) Blanchfield, J.; Toth, I., Curr. Med. Chem. 2004, 11, 1241-1253; (e) Tanikawa, T.; Fridman, M.; Zhu, W.; Faulk, B.; Joseph, I. C.; Kahne, S.; Wagner, B. K.; Clemons, P. A., Using Biological Performance Similarity To Inform Disaccharide Library Design. J. Am. Chem. Soc. 2009, 131 (14), 5075-5083.

20. Forsman, J. J.; Leino, R., L-Pentoses in Biological and Medicinal Applications. Chem. Rev. 2011, 111, 3334-3357. 
21. (a) Pachamuthu, K.; Schmidt, R. R., Synthetic Routes to Thiooligosaccharides and Thioglycopeptides. Chem. Rev. 2005, 106 (1), 160-187; (b) Driguez, H., Thiooligosaccharides as Tools for Structural Biology. ChemBioChem 2001, 2 (5), 311-318.

22. Tornoe, C. W.; Christensen, C.; Meldal, M. Peptidotriazoles on Solid Phase: [1,2,3]Triazoles by Regiospecific Copper(I)-Catalyzed 1,3-Dipolar Cycloadditions of Terminal Alkynes to Azides. J. Org. Chem. 2002, 67, 3057-3064.

23. Rostovtsev, V.; Green, L. G.; Fokin, V.; Sharpless, K. A stepwise Huisgen cycloaddition process: Copper(I)-catalyzed regioselective "ligation" of azides and terminal alkynes. Angew. Chem. Int. Ed. 2002, 41, 2596-2599.

24. Moses, J. E.; Moorhouse, A. D. The growing applications of click chemistry. Chem. Soc. Rev. 2007, 36, 1249-1262.

25. Tron, G.; Pirali, T.; Billington, R.; Canonico, P.; Sorba, G.; Genazzani, A. Click chemistry reactions in medicinal chemistry: Applications of the 1,3-dipolar cycloaddition between azides and alkynes. Med. Res. Rev. 2008, 28, 278-308.

26. Li, L.; Zhang, G.; Zhu, A.; Zhang, L., A Convenient Preparation of 5-Iodo-1,4disubstituted-1,2,3-triazole: Multicomponent One-Pot Reaction of Azide and Alkyne Mediated by CuI-NBS. J. Org. Chem. 2008, 73, 3630-3633.

24. Zemplén, G., Degradation of the reducing bioses. I. Direct determination of the constitution of cellobiose. Ber. Deutsch. Chem. Ges. 1926, 59, 1254-1266.

28. Deng, J.; Wu, Y.-M.; Chen, Q.-Y., Cross-Coupling Reaction of Iodo-1,2,3-triazoles Catalyzed by Palladium. Synthesis 2005, 16, 2730-2738.

29. Khalifah, R. G., The Carbon Dioxide Hydration Activity of Carbonic Anhydrase. J. Biol. Chem. 1971, 246 (8), 2561-2573.

30. Lopez, M.; Salmon, A. J.; Supuran, C. T.; Poulsen, S.-A., Carbonic anhydrase inhibitors developed through 'click tailing'. Curr. Pharm. Des. 2010, 16 (29), 3277-3287. 
31. Pouyssegur, J.; Sardet, C.; Franchi, A.; L'Allemain, G.; Paris, S., A specific mutation abolishing $\mathrm{Na}+/ \mathrm{H}+$ antiport activity in hamster fibroblasts precludes growth at neutral and acidic pH. Proc. Natl. Acad. Sci. USA 1984, 81 (15), 4833-4837. 


\section{Table of Contents Graphic}
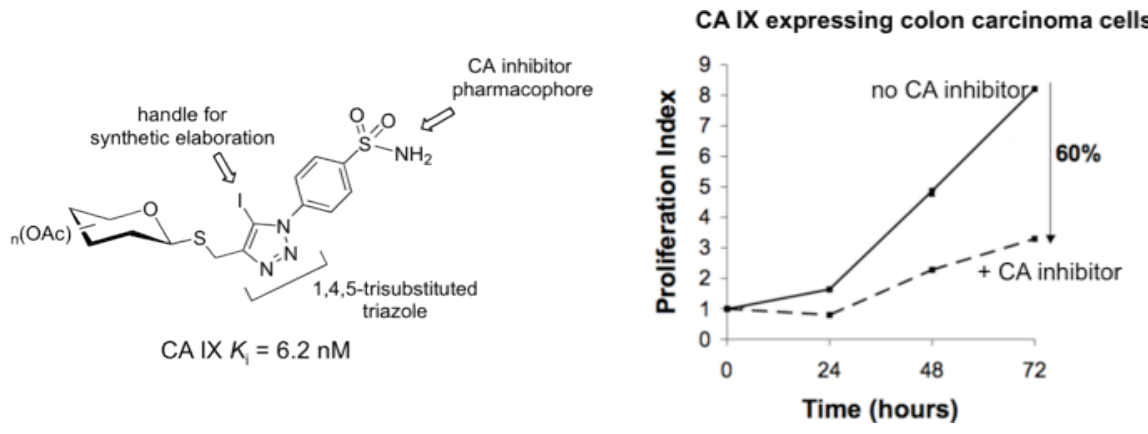